\title{
Design and Development of a Gasketless Cylinder Head / Block Interface for an Open Deck, Multi Cylinder, Highly Turbocharged Small Engine
}

\author{
William Attard and Harry C. Watson \\ University of Melbourne \\ Peter Stryker \\ Bucknell University
}

Copyright $@ 2006$ SAE International

\begin{abstract}
This paper describes the design and development of a gasketless interface, which was used successfully to couple an aluminium cylinder head to an open deck design cylinder block. The cylinder block was manufactured from aluminium, featuring shrink fit dry cast iron liners. Extensive CAE modelling was employed to implement the gasketless interface and thus avoid using a conventional metal or fiber based cylinder head gasket.
\end{abstract}

The engine was specifically designed and configured for the purpose, being a $430 \mathrm{~cm}^{3}$, highly turbocharged (TC) twin cylinder in-line arrangement with double overhead camshafts and four valves per cylinder. Most of the engine components were specially cast or machined from billets.

The new design removed the conventional head gasket and relied on the correct amount of face pressure generated by interference between the cylinder head and block to seal the interface. This had advantages in improving the structural integrity of the weak open deck design. Extensive FEM analysis determined the correct amount of interference needed for successful operation under all operating conditions.

Extensive thermal analysis concluded that removing the conventional gasket had the advantage of improving the heat path between the cylinder head and block, as the gasket behaves as an insulator. The possibility of gasket failure due to abnormal combustion is also eliminated.

The design proved successful in operation, withstanding knock amplitudes of 30 bar, in-cylinder pressures exceeding 100 bar and high combustion temperatures. The engine completed extensive static and transient testing with no interface problems after initial development, recording 25 bar brake mean effective pressure (BMEP) on pump gasoline.

\section{INTRODUCTION}

A clean sheet approach was taken in designing an engine specifically for SAE's student Formula race-car competition. From the onset, an open deck design was an obvious choice for the cylinder block due to its well published advantages in cooling and end-gas knock avoidance $[1,2,3]$. The design brief featured high pressure ratio turbocharging, with maximum values predicted to reach 2.8 at mid range speeds $[4,5,6]$. Thus all design decisions were based on preventing knock and maintaining engine reliability.

Sealing thin walled open deck designs has proven to be difficult in high BMEP normally aspirated (NA) engines, due to a lack of block structural integrity $[7,8,9]$. Excessive bore distortion is the underlying problem, which significantly increases piston blow-by. Therefore, preventing bore distortion was even more critical to the success of this program, as single compression ring pistons were relied upon for both gas sealing and oil retention.

Difficulties also existed in the procurement of a sealing gasket, due to the engine's prototype nature. Any form of gasket featured long lead times and excessive expense due to the tooling and development required, with no guarantee of sealing. Due to the type of turbocharging employed, manufacturers were very hesitant in supplying any components due to the high probability of gasket blowout. High knock intensity was expected to be encountered during the calibration phase, with accompanying piston land and gasket failures well documented for high BMEP engines $[7,10,11]$.

The first author also expressed concerns to gasket manufacturers over unacceptable limits in conventional head gasket tolerances and bore alignment. This poor alignment could lead to bore and/or gasket edges being exposed and becoming hot spots within the cylinder, 
thus increasing the likelihood of end-gas knock and/or pre-ignition. Poor alignment could also cause increased crevice volume along the periphery of the chamber, which detracts from burning the available charge energy. This reduces engine performance and increases engine out hydrocarbon ( $\mathrm{HC}$ ) emissions [11]. Applying current day gasket technology to this particular engine was considered to be risky for the reasons previously outlined, and as such, a new design was sought and developed.

\section{TEST ENGINE}

The test engine was specifically designed and developed by the first author at the University of Melbourne for use in Formula SAE. It was only the second attempt to construct a prototype engine in the competition's 25 year history [4]. The engine features a downsized, highly TC low friction design to improve efficiency, performance and packaging when compared to typical engines used in the Formula. The majority of components were manufactured in-house, with additional support from sponsors. A CAD image and specifications are shown in Figure 1 and Table 1 respectively.

Table 1: Specifications for the UniMelb 'WATTARD' engine, specifically designed for Formula SAE competition.

\begin{tabular}{|c|c|}
\hline BRAND & UniMelb 'WATTARD' \\
\hline TYPE & $\begin{array}{l}\text { Parallel twin, } \\
4 \text { stroke SI, } \\
\text { Liquid-cooled, } \\
\text { Integral clutch/transmission }\end{array}$ \\
\hline CAPACITY & $433.8 \mathrm{~cm}^{3}$ \\
\hline BORE x STROKE & $69 \times 58 \mathrm{~mm}$ \\
\hline FIRING ORDER & Unequal $\left(0^{\circ}, 180^{\circ} \mathrm{CA}\right)$ \\
\hline COMPRESSION RATIO & 10.0:1 \\
\hline COMBUSTION CHAMBER & $\begin{array}{l}\text { Pent roof, } \\
\text { Central spark plug }\end{array}$ \\
\hline VALVE ACTUATION & 8-valve DOHC \\
\hline VALVE TIMING & $\begin{array}{lll}\text { IVO } & 24^{\circ} & \text { BTDC } \\
\text { IVC } & 72^{\circ} & \text { ABDC } \\
\text { EVO } & 57^{\circ} & \text { BBDC } \\
\text { EVC } & 9^{\circ} & \text { ATDC }\end{array}$ \\
\hline LUBRICATION & Dry sump \\
\hline INTAKE & $\begin{array}{l}20 \mathrm{~mm} \text { restrictor - Dall venturi } \\
\mathrm{KEC} \text { manifold with } \mathrm{PFI} \text {, } \\
4.5 \mathrm{~L} \text { plenum volume, } \\
350 \mathrm{~mm} \text { primary intake length, }\end{array}$ \\
\hline EXHAUST & $\begin{array}{l}\text { KEC manifold } \\
2.5 \mathrm{~L} \text { plenum volume }\end{array}$ \\
\hline ENGINE MANAGEMENT & Motec M4 EMS \\
\hline TURBOCHARGER & Garrett GT12 (modified) \\
\hline CLUTCH & Multi wet plate \\
\hline TRANSMISSION & $\begin{array}{l}\text { Constant mesh, } \\
3 \text { forward gears }\end{array}$ \\
\hline
\end{tabular}
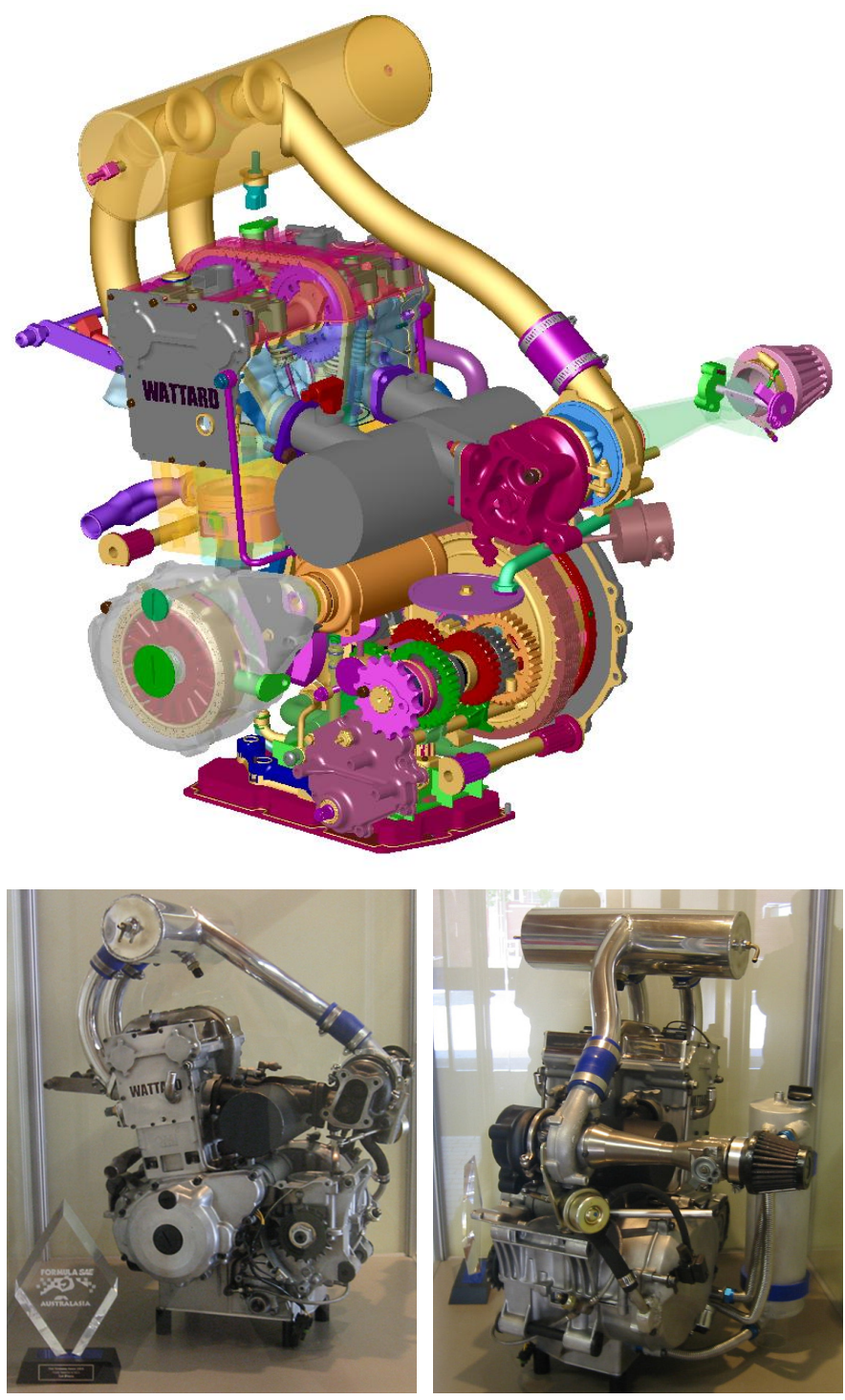

Figure 1: The UniMelb 'WATTARD' engine featuring the new gasketless interface from the initial design phase. (upper): CAD image. (lower): Final version together with the fuel economy trophy from the 2004 Australasian competition.

The design drew on the University of Melbourne's previous experience in producing small TC engines for a larger engine task, except that Formula SAE engines are significantly smaller and there was much to learn $[12,13]$. The engine research and development program introduced new powerplant concepts to the Formula. Performance and packaging improvements were aimed at improving vehicle performance, as the ultimate goal was to achieve success in Formula competition. New research findings included overcoming the well published oil consumption problems associated with throttled turbocharger compressors [4,5,14]. Other interesting research surrounded tuning an odd fire engine with an intake restriction [15] together with defining limitations for highly TC downsized engines [16]. The development program demonstrated that the challenge of looking for new ways to meet the Formula SAE rules and requirements can be more than just a training experience. 


\section{INTERFACE DESIGN}

\section{DESIGN BRIEF}

The design criteria for the gasketless interface focused on preventing combustion gas leakage under a wide range of unforgiving engine operating conditions. This included the extremes of pressure and temperature associated with highly TC motorsport applications and the potential for sustained heavy knock.

The following criteria were adhered to when designing the gasketless interface.

$>$ Sealing integrity must be sustained over the engine's life cycle, expected to be several years and hundreds of hours of operation.

$>$ The interface design should not affect the longevity of other associated components.

$>$ The cylinder bore cylindricity must be retained in the assembled state, thus minimising blow-by rates.

$>$ The design must be reusable and not suffer any sealing deterioration over its lifespan, irrespective of multiple removals during development.

$>$ The interface arrangement and other associated components need to be manufacturable using standard methods, at a cost similar to other specialized engines.

$>$ In the case of interface failure, preventive measures must be designed into the system to avoid water and/or oil entering the cylinder, hence preventing significant engine damage.

\section{LOAD CONDITIONS AND ASSUMPTIONS}

The load conditions the interface design was required to withstand were dictated by several assumptions, listed as follows.

$>$ Peak Pressure: Worse case values of 150 bar (15 $\mathrm{MPa}$ ), associated with the heavy knocking condition were assumed [11]. These values are largely dependent on the engine and flame speed but were fairly conservative.

$>$ Symmetry: Each cylinder is assumed to be independent due to the engine design featuring a central camshaft timing chain, depicted in the exploded views of Appendix A. This design forces each cylinder to have its own water jacket. The cylinder head is retained by a total of eight bolts, four per cylinder.

$>$ Loading: To ensure sealing, the cylinder head bolt tension is required to overcome the combustion force. This corresponds to $56 \mathrm{kN}$ of force per cylinder when the peak pressure condition is applied over the piston bore area.

$>$ Temperature: The average bulk water temperature is assumed to not exceed $100^{\circ} \mathrm{C}$.
$>$ Interface Contact Area: This area is dictated by the piston bore diameter and the supplied production based catalogue liners, resulting in a surface contact area of $18 \mathrm{~cm}^{2}$ between the cylinder head and liner. This arrangement results in a surface pressure of 31 $\mathrm{MPa}$ at the interface due to the force generated by the cylinder head bolt tension. This is fairly conservative in comparison to the $15 \mathrm{MPa}$ value published by Yamaguchi for a new cylinder head gasket design [8].

$>$ Safety Factor: A safety factor of 1.2 was applied to the worse case condition.

$>$ Stiffness: The cylinder head and crankcase were assumed to be infinitely stiff in comparison to the barrel assembly. Consequently, the barrel assembly conforms via elastic deformation to suit the top and bottom constraints.

$>$ Thermal expansion: As the cylinder head and base barrel were manufactured from aluminium, differential thermal expansion effects and resultant interface loading were assumed to be negligible when compared to combustion loading. The temperature induced axial liner loading on the cylinder head was also expected to be minimal and hence ignored due to the thin walled liner section.

\section{BARREL AND LINER DESIGN}

The gasketless interface, as indicated by the name, requires no specific gasket or components to seal combustion gases between the cylinder head and block assemblies. This task is instead performed by the barrel and liner assembly, which must also fulfil its normal duties associated with piston motion and heat transfer.

Before including the interface effects into the barrel and liner design, decisions were finalised to fulfil requirements associated with cost, performance, reliability and delivery times. These are listed below, in order of importance.

$>$ The assembly was constructed of a one piece barrel with removal dry liners. This reduced development time and costs in the case of bore damage.

> An open deck water cooling jacket design was chosen to allow full peripheral water cooling around the cylinder bore and up to the cylinder head deck surface. However, the closed deck design has been proven to be more effective in cylinder head gasket sealability due to its superior structural integrity [8].

$>$ The removable liners chosen were production based catalogue items, manufactured from grey cast iron. These liners had the potential to be replaced by Nikasil coated aluminium liners which have more favourable frictional and heat transfer properties. The thermal analysis presented later assumes the aluminium liners were used.

> The base barrel was CNC machined from billet due to the low volumes required. A 6000 series aluminium, specifically 6061-T6, was chosen due to 
its heat transfer properties, high yield strength, excellent machinabilty and reparability.

$>$ The water cooling jacket design was dictated by manufacturing techniques and packaging restrictions. This resulted in water cooling the top $75 \%$ of the piston stroke. Cooling the bottom portion of the bore was considered to have only a minor effect, due to the four fold reduction in local heat flux values from the top to the bottom of the cylinder [1].

The final barrel and liner assembly design, incorporating the gasketless interface, is shown in Figure 2. For the reader to gain some visual understanding of the assembly and how it interacts with associated components, exploded views are displayed in Appendix A.

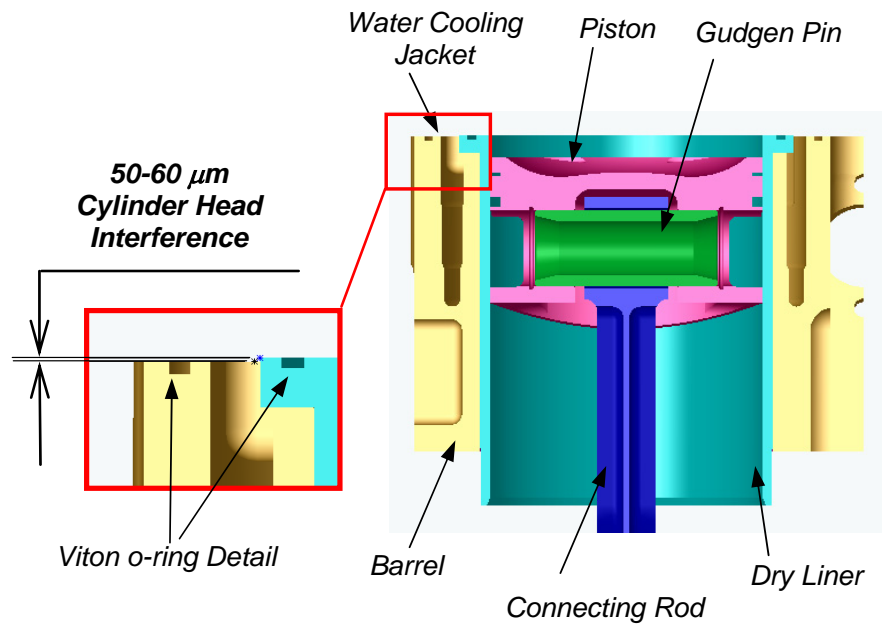

Figure 2: Section view highlighting the barrel and liner assembly featuring the gasketless sealing arrangement with the cylinder head not installed.

In order for the interface to successfully seal combustion gas, continuous surface pressure, rather than line pressure on the cylinder bore decks is required [8]. This was achieved by shrink fitting the cast iron liners into the aluminium base barrel and then machining the liner surface proud, in comparison to the barrel deck surface. This ensured that the surface pressures would be highest between the liner and cylinder head surfaces when the cylinder head was installed, thus creating a robust seal.

The purpose of shrink fitting the liners into the barrel was to provide the high positional accuracy and alignment, needed to ensure the liners remained in position under all operating conditions. A H7-p6 locational interference fit was chosen, which ensured the liners remained fixed in the barrel under worse case conditions. These conditions corresponded to engine motoring at the maximum bulk water temperature of $100^{\circ} \mathrm{C}$. Under all other operating conditions, firing ensured higher liner temperatures and thus increased the shrink fit interference. Table 2 displays the upper and lower bounds of the fit, with tight tolerances on drawings needed to ensure a positive interference at the motoring condition.
Table 2: H7-p6 locational shrink fit upper and lower limits at ambient temperature and worse case conditions.

\begin{tabular}{|c|c|c|}
\hline H7-p6 & $\begin{array}{c}\text { Shrink fit } \\
\text { interference }(\mu \mathrm{m}) \text { at } \\
\text { ambient, } 20^{\circ} \mathrm{C}\end{array}$ & $\begin{array}{c}\text { Shrink fit } \\
\text { interference }(\mu \mathrm{m}) \text { at } \\
\text { motoring, } 100^{\circ} \mathrm{C}\end{array}$ \\
\hline MAX & +93 & +33 \\
\hline MIN & +37 & -23 \\
\hline AVER & $+\mathbf{+ 6 5}$ & $+\mathbf{5}$ \\
\hline
\end{tabular}

The liner fitting process involved oven heating the base aluminium barrel to $80^{\circ} \mathrm{C}$ and chilling the cast iron liners, with the change in dimensions via thermal effects allowing sufficient clearance for assembly. This process could also be reversed if the liners needed to be replaced. The temperatures associated with shrink fitting were below the aging temperature of the aluminium and thus did not affect the mechanical properties

The gasketless interface has the potential to seal combustion gas, cooling water and lubrication oil as per the requirements of a conventional head gasket. However, some redundancy was built into this design to ensure reliability in case of failure due to the engine's prototype nature. The primary purpose of the gasketless interface was to seal combustion gas, with o-ring seals independently used to restrain cooling water and oil. For a limited time, these o-ring seals could also seal combustion gas in the case of interface failure. O-ring grooves were positioned nearer to the water jacket, aiding in their longevity due to the lower local temperatures. This also ensured that adequate surface contact area could be retained to seal the interface. A Viton o-ring material was chosen due to its low cost and ability to withstand continuous temperatures above $200^{\circ} \mathrm{C}$. A sectional view highlighting the o-ring locations is also shown in Figure 2.

Figure 3 displays a sectional view of the assembled engine with the gasketless interface highlighted. As can be seen, the cylinder head loading from the bolt tension, has forced the portion of the barrel in contact with the liner to compress around the periphery of the bore. The compression has generated a bond between the cylinder head and the liner due to the high face pressures, preventing the liner from moving radially. In comparison, a conventional metal or fibrous based gasket allows some radial liner movement due the compliant nature of the gasket material $[7,8,9]$. Thus, the gasketless design is expected to improve the structural integrity of the weak open deck design.

For the interface to remain serviceable throughout its design life, only elastic compression was permissible, thus allowing the assembly to return back to its original unloaded position as depicted in Figure 2. The correct amount of interference required to remain in the elastic region while ensuring adequate face pressure to generate a robust seal was determined using FEM analysis, with results shown in Figure 4. 


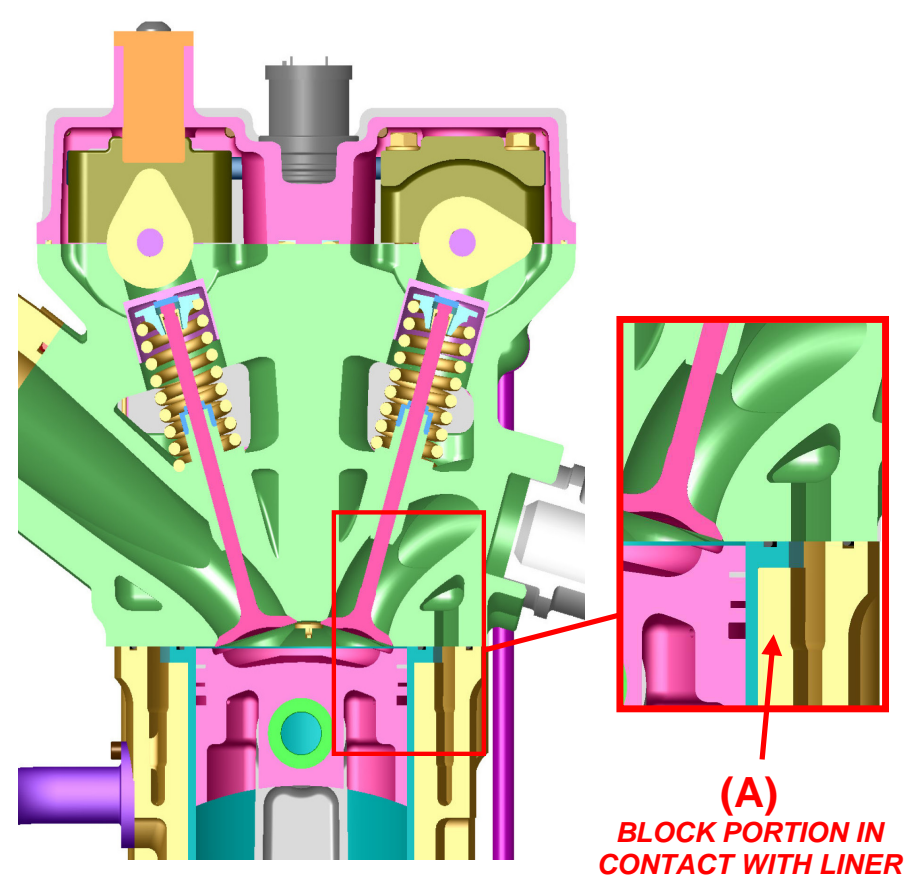

Figure 3: Assembled section view highlighting the barrel and liner sealing arrangement. The cylinder head causes the barrel to elastically distort, thus creating a robust seal.

With the previously determined loads applied to the FEM model, a liner vertical displacement of $50-60 \mu \mathrm{m}$ was simulated via the elastic deformation of area $A$, previously defined above in Figure 3 . This value is the vertical height difference between the liner and barrel decks needed to create a robust seal. The resultant stress from the cylinder head bolt tension creates peak stresses in the region of $50 \mathrm{MPa}$ in the aluminium barrel, well below the $276 \mathrm{MPa}$ yield strength of the material. In the FEM analysis, the cylinder head and crankcase are assumed to be infinitely stiff and the liner is assumed to move axially, due to the high forces generated by the cylinder head bolt tension.
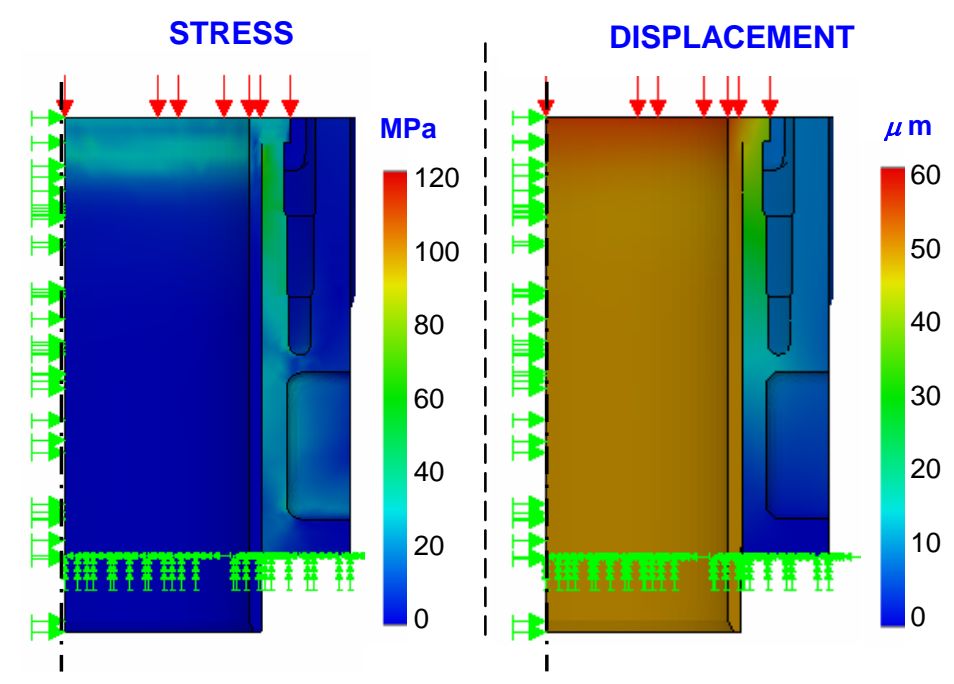

Figure 4: 1/4 FEM model analysis simulating cylinder head loading on the barrel and liner assembly. (left): Von Mises stress distribution. (right): Resultant displacement
Torque plate honing is a method commonly used in closed deck cylinder block manufacturing, where the loading from the cylinder head bolt tension around the threaded holes in the block distorts the deck. This results in bore distortion [9] as the threaded holes are generally in close proximity to the bore. This bore distortion can be significantly reduced by attaching a torque plate fixture to the cylinder block to simulate the distortion prior to its final manufacturing process $[17,18]$. A torque plate is essentially a dummy cylinder head with bore access holes to allow access for the final honing operation.

Torque plate honing has been used for decades in the high performance aftermarket and motorsport industries. In recent times, it has become more prevalent in OEM production engines. Minimising the amount of bore distortion has obvious advantages in reducing piston ring blow-by and oil consumption, as a result of the improved initial seal generated between the piston rings and the bore. This significantly reduces the run-in time and improves the cycle life of many components including the piston, piston rings and bore surface, thus increasing engine reliability and longevity [18]. As per the new gasketless design, significant barrel and liner elastic deformation causes the bore to distort when the cylinder head is assembled, due to the high face pressures needed to seal the interface. Torque plate honing can be used to minimize this distortion. However, its application differs as near zero deflection is associated with the threaded bolt holes due to the open deck design, with the majority of distortion associated with the interface.

The engine differs to conventional one piece block designs, in that it consists of multiple components including a split crankcase featuring an integral clutch, gearbox and barrel assembly. This makes it more difficult to apply torque plate honing to this type of engine. It was unfeasible to complete the process with the barrel attached to the crankcase due to the compactness of the design and bore access restrictions. However, it was assumed that the crankcase acted as a rigid one piece body due to the high number of bolts used at joints. Thus, the crankcase was replaced by an infinitely stiff fixture which restrained the bottom of the barrel but also allowed bore access.

Physical load deflection testing was completed in order to finalise the torque plate design and determine the material and thickness required to simulate the cylinder head deck stiffness. FEM analysis was avoided due to the difficulties associated with modelling the cylinder head casting irregularities and inconsistent material properties. The schematic and experimental setup is displayed in Figure 5, showing the load locations (F) and resultant deflections (D1-D4). The load was applied via a hydraulic press, with a dial indicator used for deflection measurement. An infinitely stiff fixture, replicating the interface contact region was used as a substitute for the 
barrel and liner assembly, thus ensuring all deflection occurred in the cylinder head

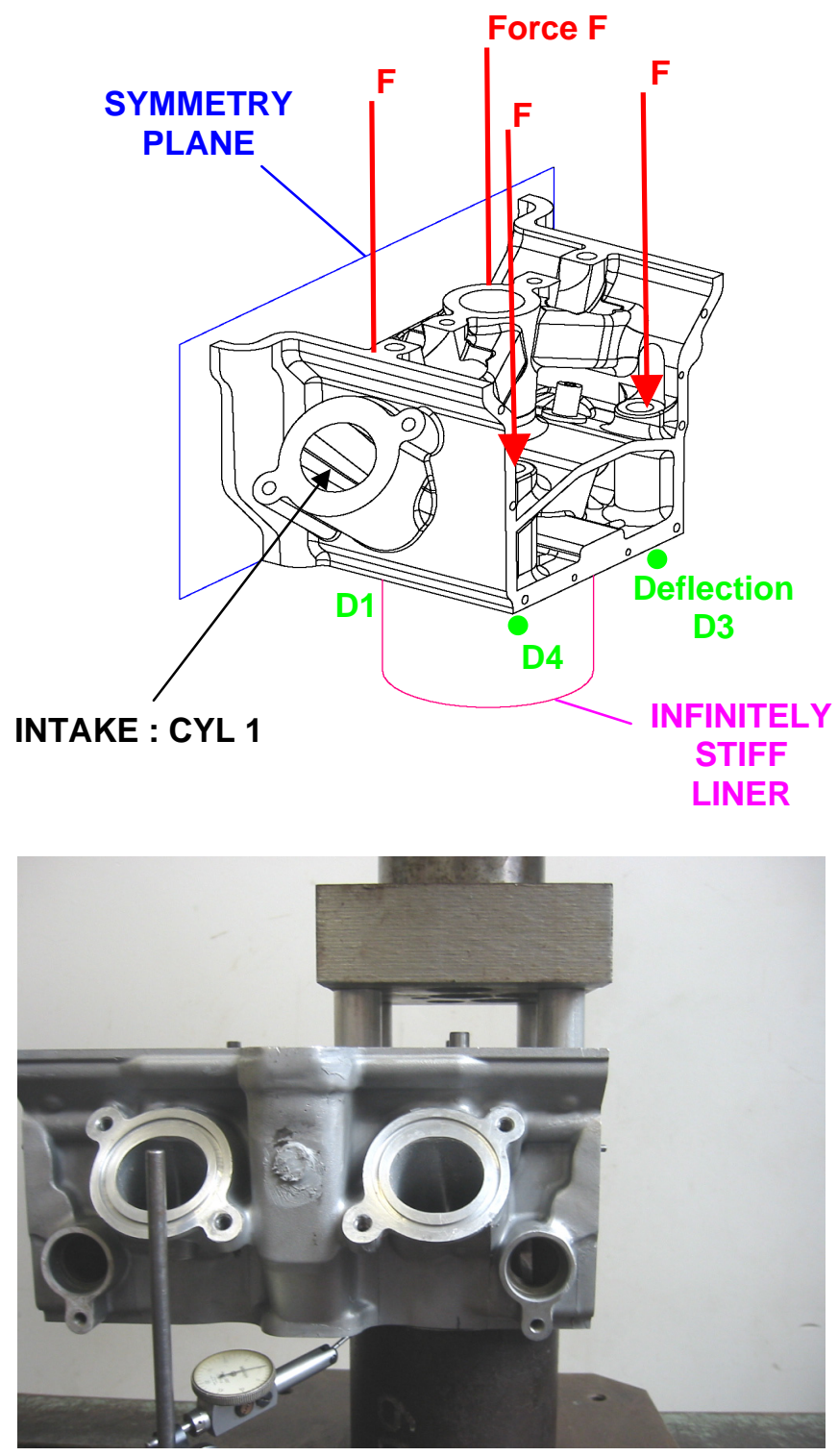

Figure 5: Cylinder head stiffness measurement, needed for torque plate design. (upper): Schematic highlighting loaded locations (F) and deflections (D). (lower): Physical testing performed.

Results from load deflection testing are shown in Figure 6 , with trends suggesting that the deck stiffness varies between the inner and outer bolt locations. This was anticipated as the cylinder head featured open ends with exposed water jacket detail, shown more clearly in the exploded views of Appendix A. Using the cylinder head experimental data, specifications concerning the torque plate were finalized with the aid of the FEM analysis shown in Figure 7. Final dimensional thickness was determined to be $40 \mathrm{~mm}$ when manufactured from mild steel via laser cutting, with the surface ground flat to replicate the cylinder head deck surface.

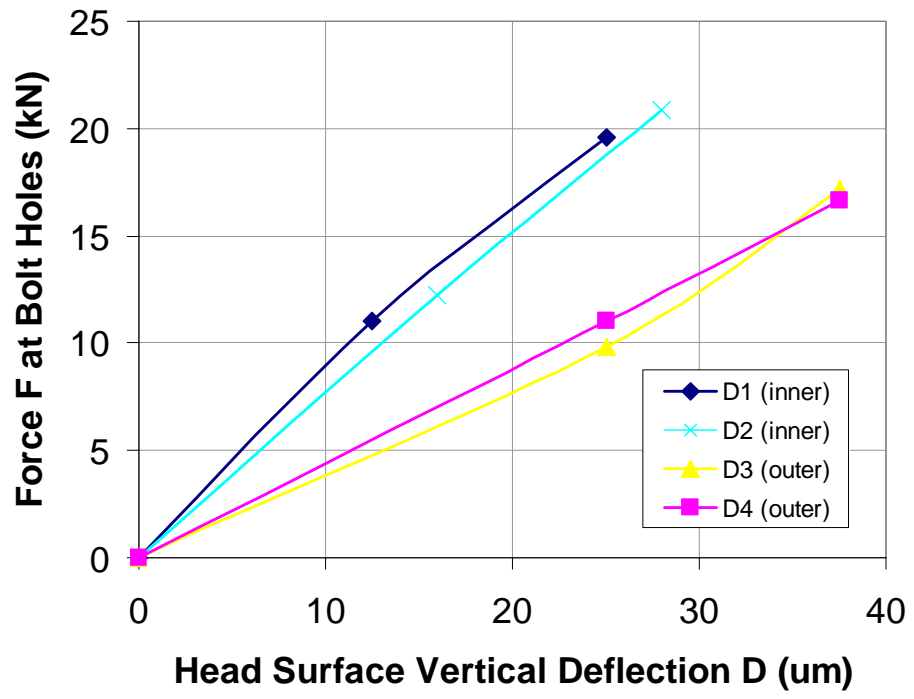

Figure 6: Results from load deflection tests performed on the cylinder head to determine the relative cylinder head stiffness needed for the torque plate design.
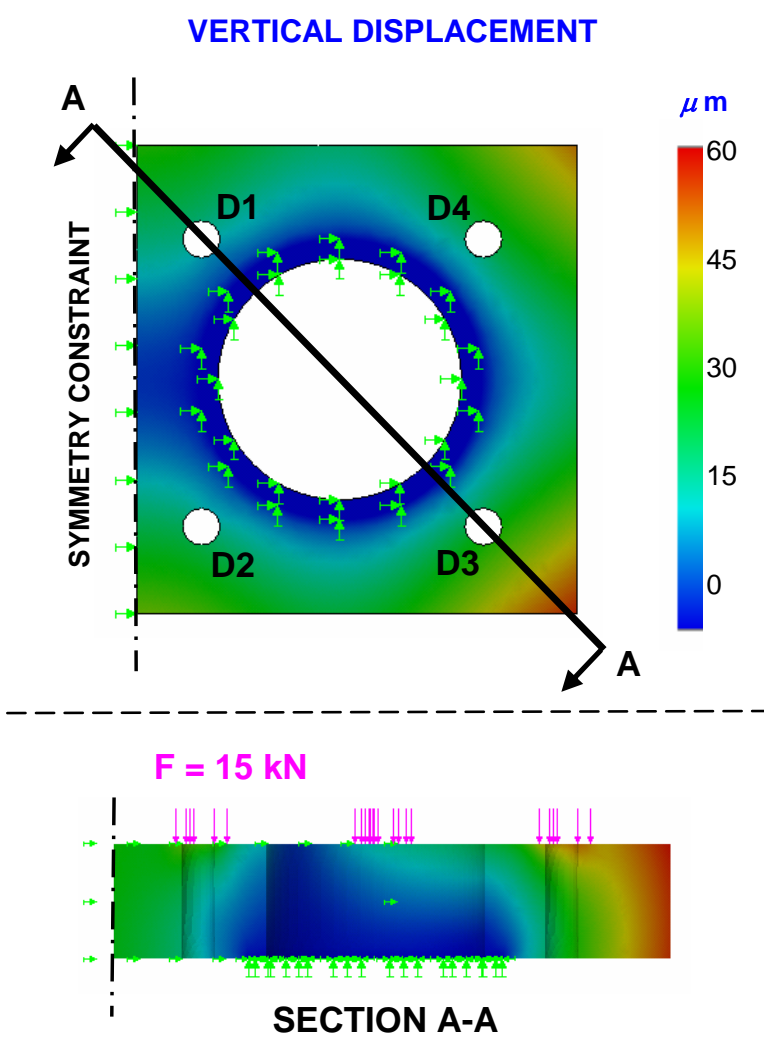

Figure 7: $1 / 2$ FEM model analysis simulating torque plate effects to determine the thickness needed to represent the cylinder head. (top): Vertical displacement. (bottom): Vertical displacement along section A-A. 


\section{THERMAL ANALYSIS}

A thermal FEM analysis was completed for the engine to determine the affect of the gasketless design on the surface temperatures of the cylinder head and the liner at the operating conditions of peak pressure and exhaust blow-down. The critical areas were assumed to be the bridges (exhaust-exhaust, intake-intake and intakeexhaust). To analyse these areas, two sets of models were created with the CAD images depicted in Figure 8.
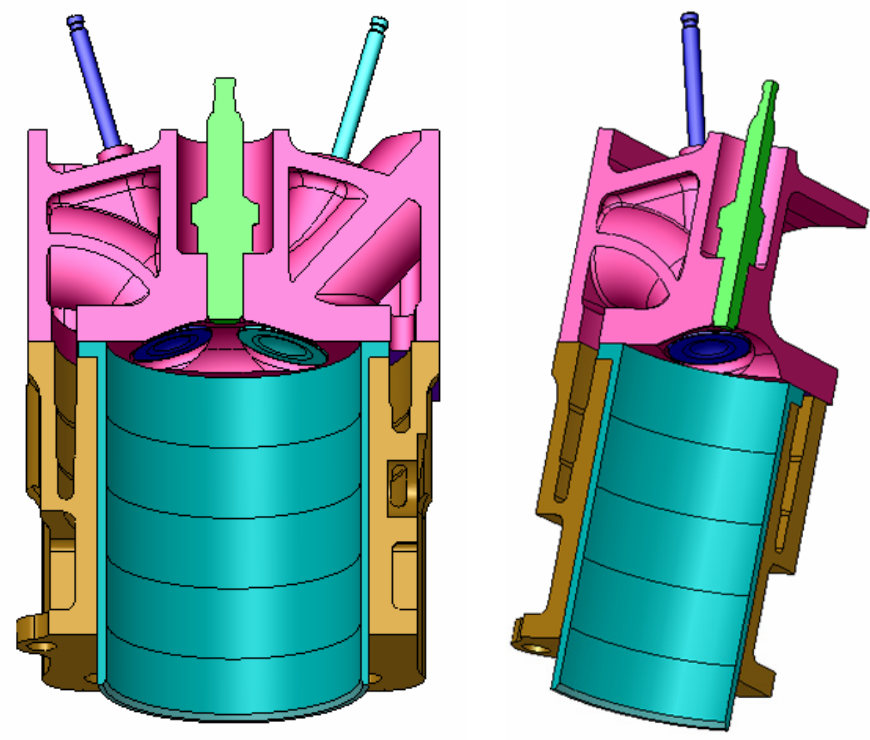

Figure 8: $1 / 2$ and $1 / 4$ CAD models used in the thermal FEM analysis.

The first set contained $1 / 2$ cylinder models, created along the plane of symmetry through the exhaust valve bridge to the intake valve bridge. One model featured the gasketless interface, while the other had a $1 \mathrm{~mm}$ thick gasket between the cylinder head and block. Both valves were closed in this set. The $1 / 4$ model created by sectioning through the exhaust valve and intake-exhaust valve bridges was used in the second set. This set contained four models, distinguished by having a gasket or not and whether or not the exhaust valve was open 2 $\mathrm{mm}$ or closed.

\section{BOUNDARY CONDITIONS}

The $1 / 2$ models were created to represent conditions during combustion while the $1 / 4$ models were created to represent conditions during combustion and exhaust blow-down. The boundary conditions applied for each of the models are listed in Tables 3 and 4 . The combustion phase boundary conditions were estimated using the following criteria:

$>$ The convective heat transfer coefficients used for the combustion surface were calculated using the operating conditions $\left(T_{\text {gas }}, P_{\text {cylinder }}\right)$ at peak pressure with the Woschni correlation [19].

> The convective correlation for the top $20 \mathrm{~mm}$ of the bore surface were assigned values equal to half that of the combustion surface [20].
$>$ The exhaust port convective coefficient was calculated using the equation given by Heywood for the exhaust valve closed [21].

$>$ The fixed bore temperatures and the cylinder head and bore water jacket surface temperatures were assigned values based on Clough's paper [1].

Table 3: Boundary conditions associated with combustion used in all steady state thermal FEM analysis.

Boundary conditions associated with combustion

\begin{tabular}{|c|c|c|c|c|}
\hline & type & $\begin{array}{c}\text { fixed } \\
\text { temp }\left({ }^{\circ} \mathrm{C}\right)\end{array}$ & $\begin{array}{c}\text { gas temp } \\
\text { (Kelvin) }\end{array}$ & $\begin{array}{c}\text { convective } \\
\text { coefficient } \\
\left(\mathrm{W} / \mathrm{m}^{2} \mathrm{~K}\right)\end{array}$ \\
\hline $\begin{array}{l}\text { Cylinder } \\
\text { top } 20 \mathrm{~mm} \text { of liner } \\
20-40 \mathrm{~mm} \text { of liner } \\
40-60 \mathrm{~mm} \text { of liner } \\
60-80 \mathrm{~mm} \text { of liner } \\
80-100 \text { of liner } \\
\text { block water jacket } \\
\text { Valves } \\
\text { valve face } \\
\text { valve edge } \\
\text { upper valve stem } \\
\text { lower valve stem } \\
\text { Head } \\
\text { head combustion surface } \\
\text { exhaust port } \\
\text { head water jacket }\end{array}$ & $\begin{array}{c}\text { conv } \\
\text { temp } \\
\text { temp } \\
\text { temp } \\
\text { temp } \\
\text { temp } \\
\\
\\
\text { conv } \\
\text { perfect contact } \\
\text { temp } \\
\text { conv } \\
\\
\\
\text { conv } \\
\text { conv } \\
\text { temp }\end{array}$ & $\begin{array}{c}140 \\
130 \\
135 \\
140 \\
95\end{array}$ & $\begin{array}{l}2853 \\
800\end{array}$ & $\begin{array}{l}2000 \\
200\end{array}$ \\
\hline
\end{tabular}

For the exhaust phase, the boundary conditions were determined using experimental temperature and pressure data at the $2 \mathrm{~mm}$ open exhaust valve position.

$>$ Values were applied to calculate a combustion surface convective coefficient using the Woschni correlation [19].

$>$ The convective coefficient for the exhaust port calculated using an equation published by Heywood [21].

$>$ The bottom $80 \mathrm{~mm}$ of the bore was assigned a fixed temperature [1].

Table 4: Boundary conditions associated with exhaust blowdown used in all steady state thermal FEM analysis.

Boundary conditions associated with exhaust blow-down

\begin{tabular}{|c|c|c|c|c|}
\hline & type & $\begin{array}{c}\text { fixed } \\
\text { temp }\left({ }^{\circ} \mathrm{C}\right)\end{array}$ & $\begin{array}{c}\text { gas temp } \\
\text { (Kelvin) }\end{array}$ & $\begin{array}{c}\text { convective } \\
\text { coefficient } \\
\left(\mathrm{W} / \mathrm{m}^{2} \mathrm{~K}\right)\end{array}$ \\
\hline $\begin{array}{l}\text { Cylinder } \\
\text { top } 20 \mathrm{~mm} \text { of liner } \\
20-40 \mathrm{~mm} \text { of liner } \\
40-60 \mathrm{~mm} \text { of liner } \\
60-80 \mathrm{~mm} \text { of liner } \\
80-100 \text { of liner } \\
\text { block water jacket } \\
\text { Valves } \\
\text { valve face } \\
\text { valve edges } \\
\text { lower valve stem } \\
\text { upper valve stem } \\
\text { Head } \\
\text { head combustion surface } \\
\text { exhaust port } \\
\text { head water jacket }\end{array}$ & $\begin{array}{l}\text { conv } \\
\text { conv } \\
\text { conv } \\
\text { temp } \\
\text { temp } \\
\text { temp } \\
\\
\text { conv } \\
\text { conv } \\
\text { conv } \\
\text { temp } \\
\\
\text { conv } \\
\text { conv } \\
\text { temp }\end{array}$ & $\begin{array}{c}135 \\
140 \\
95\end{array}$ & $\begin{array}{l}1300 \\
1100 \\
1100\end{array}$ & $\begin{array}{l}1300 \\
1200 \\
1200\end{array}$ \\
\hline
\end{tabular}




\section{SOLUTION METHOD}

COSMOS-Works ${ }^{\circledR}$ was used to mesh the model, apply boundary conditions and solve for a steady state solution. Although the convective boundary conditions were intended to be used with a transient analysis, it was felt that they gave the proper proportional relationship for the different coefficients as applied to the different surfaces. The steady state solution would give surface temperatures much higher than a transient solution at a specific crank angle, however the temperature relationship between the models should be consistent. This hypothesis was validated by varying the convective coefficient and ambient temperatures associated with the boundary conditions. Although results showed magnitude changes in temperature, the relationship between the models remained consistent. Additionally, the resulting temperature distributions were similar (although with higher values) to those found in the literature $[1,20,22,23,24]$. Therefore, the boundary conditions used in this analysis were appropriate for the intended qualitative analysis.

Although the plane through the exhaust-intake bridge that formed the $1 / 4$ model was not truly adiabatic, results from the $1 / 2$ model indicate that an adiabatic assumption for this plane would have little affect on the resulting temperature distribution or temperature differences. The relatively symmetrical temperature pattern in the bridge area can be seen in Figure 9.

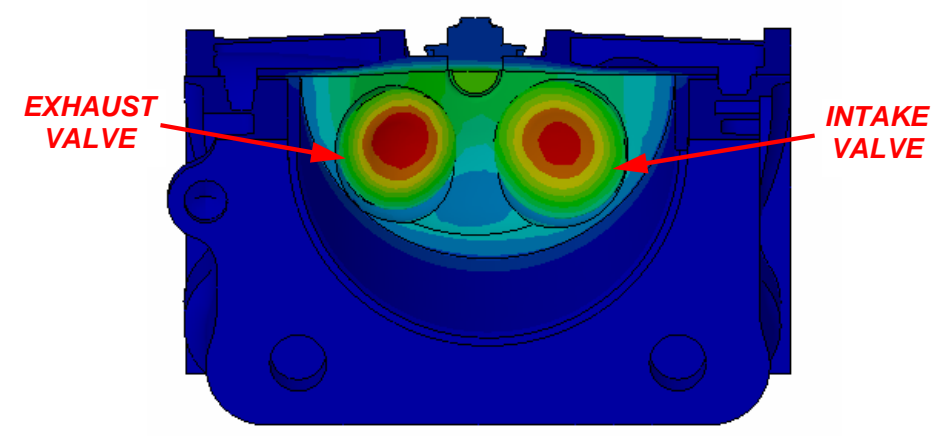

Figure 9: Temperature distribution on the combustion surface for the $1 / 2$ model, indicating that the adiabatic assumption through the intake exhaust plane can be assumed for the $1 / 4$ model.

\section{THERMAL RESULTS}

A steady state analysis was completed with $1 / 2$ model results shown in Figures 10 and 11 and $1 / 4$ model results in Figure 12. Figure 10 shows a comparison of head surface temperatures along the plane of symmetry for the gasket and gasketless models at peak pressure. The gasketless model has lower surface temperatures when compared to the gasket model at each location. This occurs as the metal to metal contact at the interface allows increased heat (thermal energy) to flow from the head to the liner. The difference between the models is most noticeable near the interface region and becomes negligible towards the centre of the bore. This has relevance as it indicates potential reductions in end-gas temperature, thus decreasing the likelihood for knock to occur in this region $[3,11]$. It is also noted that at the interface, the temperature differential was higher on the exhaust side when compared to the intake, as expected.

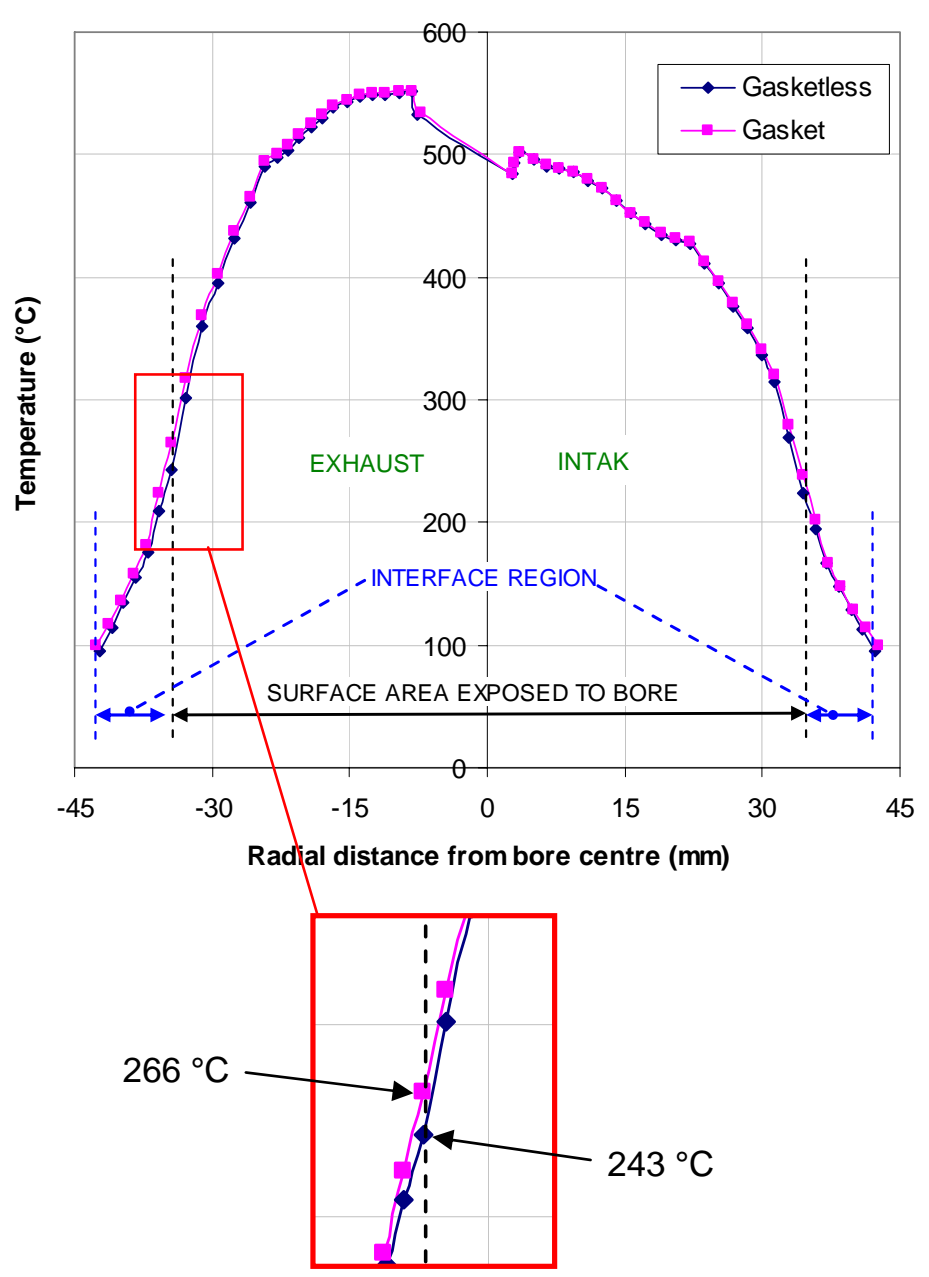

Figure 10: Cylinder head surface temperatures at peak combustion pressure along the symmetry plane line for the $1 / 2$ model. The area highlighted indicates the reduced temperature due to the gasketless interface.

Figure 11 shows the bore surface temperatures as a function of distance from the bottom of the cylinder head on the exhaust side. The gasket model results show a large temperature gradient across the face of the gasket surface due to the low thermal conductivity of the gasket. The results confirm the findings of Figure 10, with the lower surface temperatures of the cylinder head resulting in higher liner surface temperatures due to the increased heat flux at the interface for the gasketless model. 


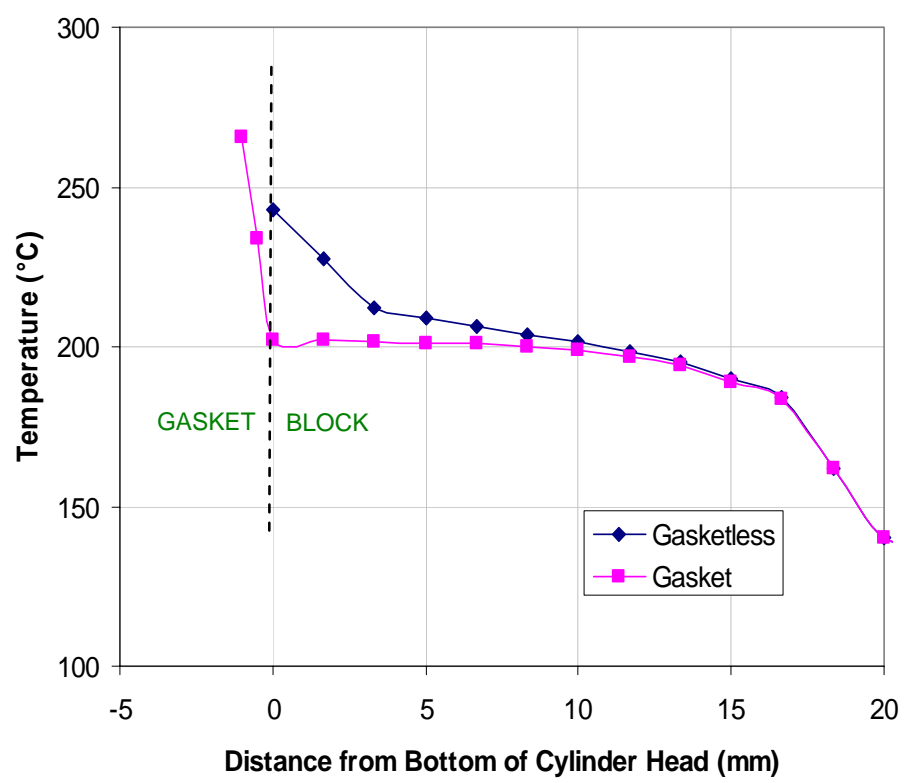

Figure 11: Liner surface temperatures at peak combustion pressure along the symmetry plane line on the exhaust side for the $1 / 2$ model.

Two sets of data are presented in Figure 12. Both sets depict the cylinder head surface temperatures at nodes along the planes used to form the $1 / 4$ model, starting at the exhaust valve bridge and ending at the intakeexhaust valve bridge. This figure confirms that the gasketless model has lower temperatures than the gasket model, as previously shown in Figure 10.

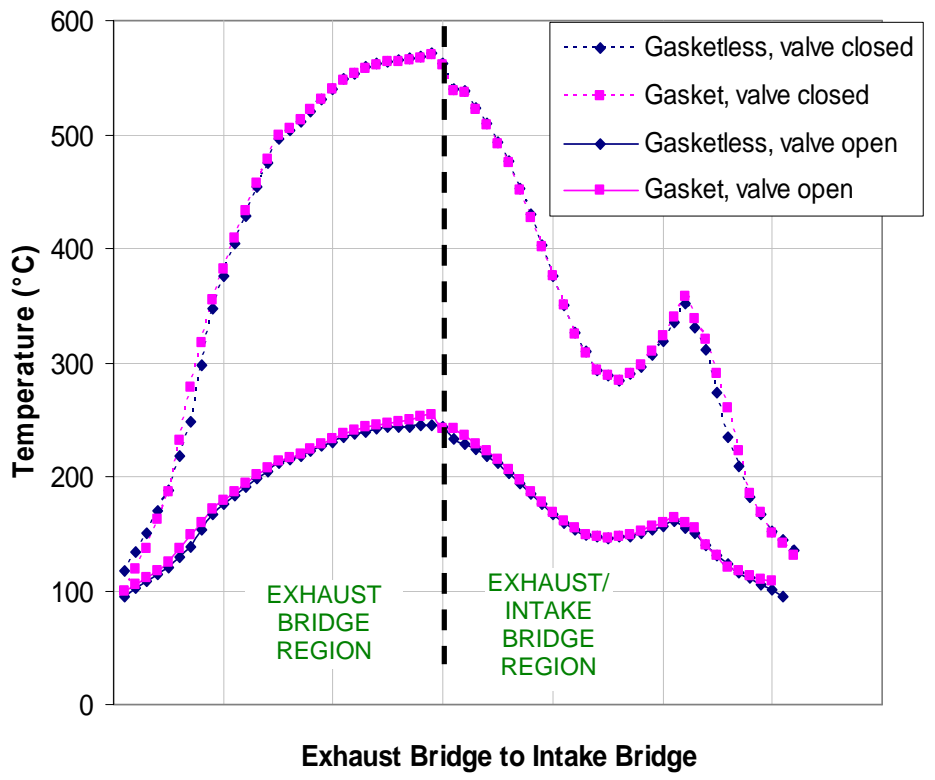

Figure 12: Cylinder head surface temperatures for peak combustion pressure and exhaust blow down models along the planes defining the $1 / 4$ model.
The effect of the variation in the cylinder head wall thickness on surface temperatures is evident by the dip in the head surface temperature plots. It should also be noted that the temperature pattern and values in the vicinity of the exhaust valve bridge are similar for the half and quarter models. The other set of data shown is for the same surface when the exhaust valve is open. The same pattern is evident, although at much lower temperatures corresponding to the exhaust phase boundary conditions.

\section{INITIAL DEVELOPMENT}

\section{MANUFACTURING AND ASSEMBLY}

Due to the short time scale of the engine program and budget limitations, there was little choice but to manufacture the barrel and liners concurrently. This was expected to be problematic due to the unknown bore distortion effect from shrink fitting the liner into the barrel. However, this was likely to be minimal due to the slight interference between both parts. It was assumed from earlier FEM analysis that the majority of distortion would occur when the torque plates were installed prior to honing.

As both items were machined from billet, drawings were issued with tight tolerances on critical dimensions to ensure the correct interference when assembled. To minimise time loss, the barrel and liners were finished machined with $\mathrm{a}+50 \mu \mathrm{m}$ bore honing allowance to later match the custom forged pistons, which as yet had not been delivered.

This method of manufacture was extremely problematic and expensive. Although both barrel and liner bores were concentric and consistent in diameter along the length of the bore prior to assembly, significant bore distortion occurred when the liners were shrink fitted. Although the bore had remained concentric, it was no longer consistent in diameter, with the top being $25 \mu \mathrm{m}$ larger than the bottom.
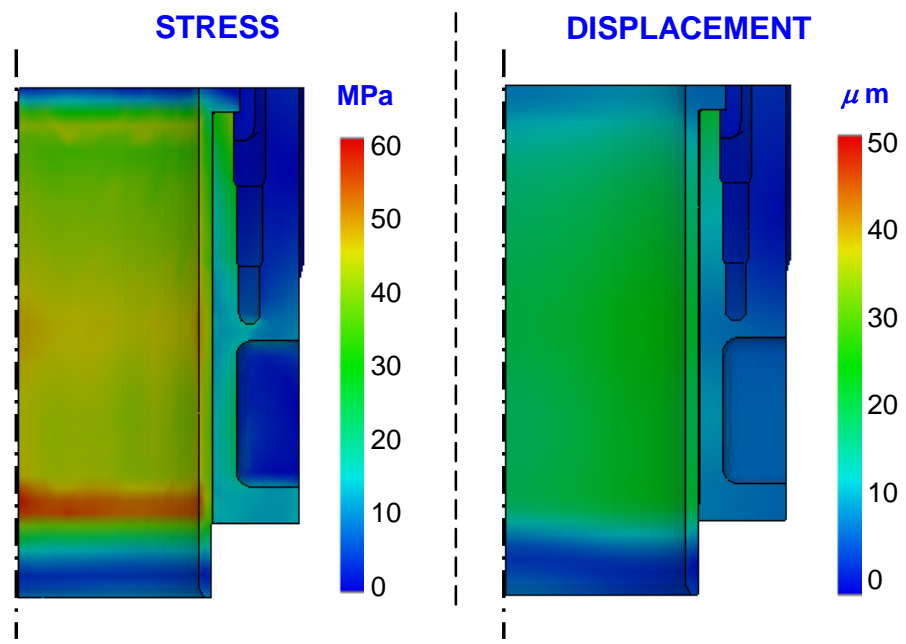

Figure 13: 1/4 FEM model analysis simulating the H7p6 shrink fit between the barrel and liner. (left): Von Mises stress distribution. (right): Resultant displacement. 
This variation was a result of inconsistent hoop stresses generated as a result of the varying barrel wall thickness, with the top allowing more radial deflection than the bottom. This is confirmed in Figure 13, which displays the resultant stresses and deflections generated via the shrink fit, with the FEM analysis performed after assembly. The analysis clearly shows that all displacement occurs radially, with higher stress bands in the liner. This occurs as the barrel allows less deflection due to the increased wall section which is reinforced in the middle and lower portions. However, the upper unsupported water jacket region allows both components to radially deflect, with similar local stress bands.

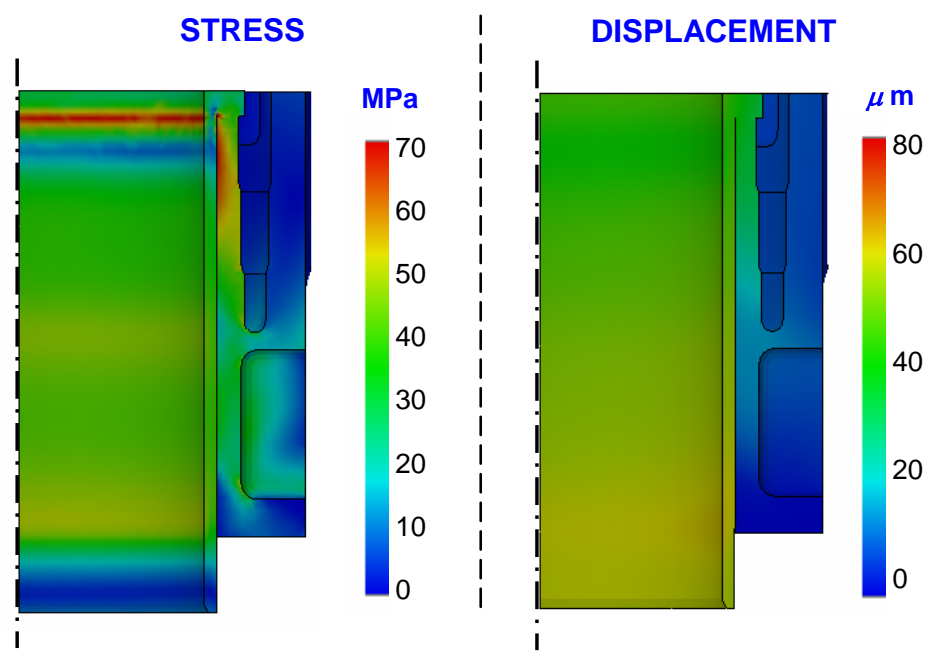

Figure 14: 1/4 FEM model analysis simulating both the shrink fit and torque plate effects. (left): Von Mises stress distribution. (right): Resultant displacement.

The experienced bore diameter inconsistencies were further magnified after torque plate installation, as confirmed by the FEM analysis in Figure 14 . The analysis shows that the torque plate loading effects are dominant, but highlighted that the shrink fit effects can not be ignored. This bore inconsistency, resulted in increasing the honing difficulty, with the finished bore size varying by $25 \mu \mathrm{m}$ in diameter and concentricity. This was not ideal, but with approaching deadlines, engine assembly and commissioning continued.

\section{INITIAL TESTING}

From the onset, piston blow-by rates were high with no significant reduction after initial engine run-in and several hours of operation. Blow-by rates significantly increased as load increased, halting testing for disassembly and inspection purposes.

Figure 15 displays some findings of concern, with close inspection revealing abnormal carbon deposits on the cylinder head and liner mating surfaces. This could only be explained by combustion gas leaking into this area as a result of the failed interface. The high blow-by rates observed during testing were a result of leakage past the top piston ring which are further highlighted in Figure 15.
This problem was further enhanced via the first iteration piston design, which featured only one single compression ring. The high blow-by rates could be attributed to bore dimensional irregularities associated with the manufacturing process previously described. However, the failed interface could not be explained at the time.

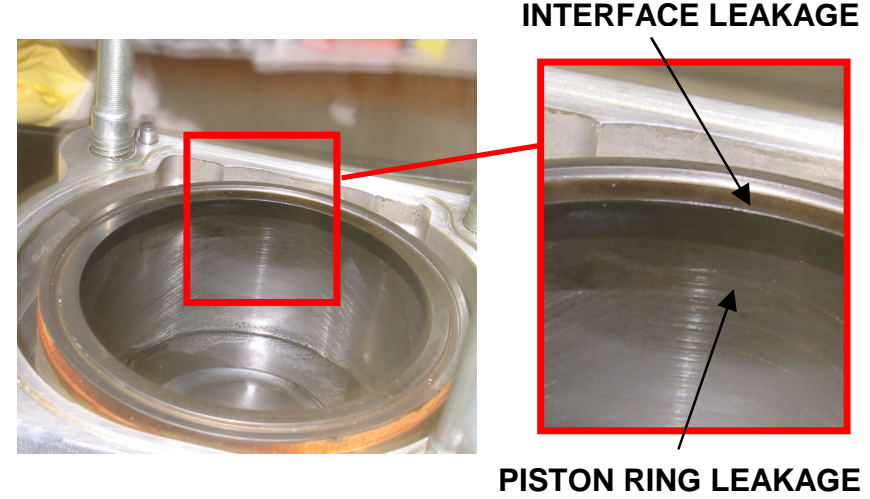

Figure 15: Failed gasket interface with clear signs of leakage between the cylinder head and liner mating surfaces. High piston ring leakage is also evident.

\section{FAILURE ANALYSIS}

Two major problems were evident after initial development. The first involved how to manufacture the assembly within specified tolerances. The other involved the amount of interference needed to produce the required face pressure to ensure a robust interface seal.

\section{MANUFACTURING PROCESS ALTERATION}

The manufacturing procedure was altered to accommodate the deflection from the shrink fit and torque plate loading. This included an extra $0.5 \mathrm{~mm}$ allowance on the liner inside bore, which had only a minor effect on shrink fit deflection. This extra allowance allowed the final bore machining to be completed after shrink fitting, with the addition of torque plate loading.

The following manufacturing process ensured the bores remained concentric and consistent in diameter when the cylinder head was installed.

1. The liner's outside diameter (OD) was machined to match the barrel inside diameter (ID) and the associated shrink fit.

2. A $0.5 \mathrm{~mm}$ extra allowance was left on the ID of the liners and the interface sealing face.

3. Liners were installed into the barrel via shrink fitting.

4. The liner deck surface was machined to specified tolerances above the barrel deck surface to achieve the required interference.

5. The bottom fixture was installed followed by the torque plate.

6. The liner's ID bore was machined and then honed to match the supplied pistons. 


\section{INTERFACE LEAKAGE}

The interface failure was caused by insufficient face pressure between both surfaces. The logged data confirmed that the measured in-cylinder pressures were well below the worse case design pressure, with additional error margin in the safety factor assumption. However, original calculations assumed the cylinder head was a rigid solid body with zero deflection in magnitude compared to the barrel and liner assembly. This assumption was later proven to be incorrect by the physical load deflection tests displayed in Figure 5, and later confirmed by the FEM analysis of Figure 16 below.
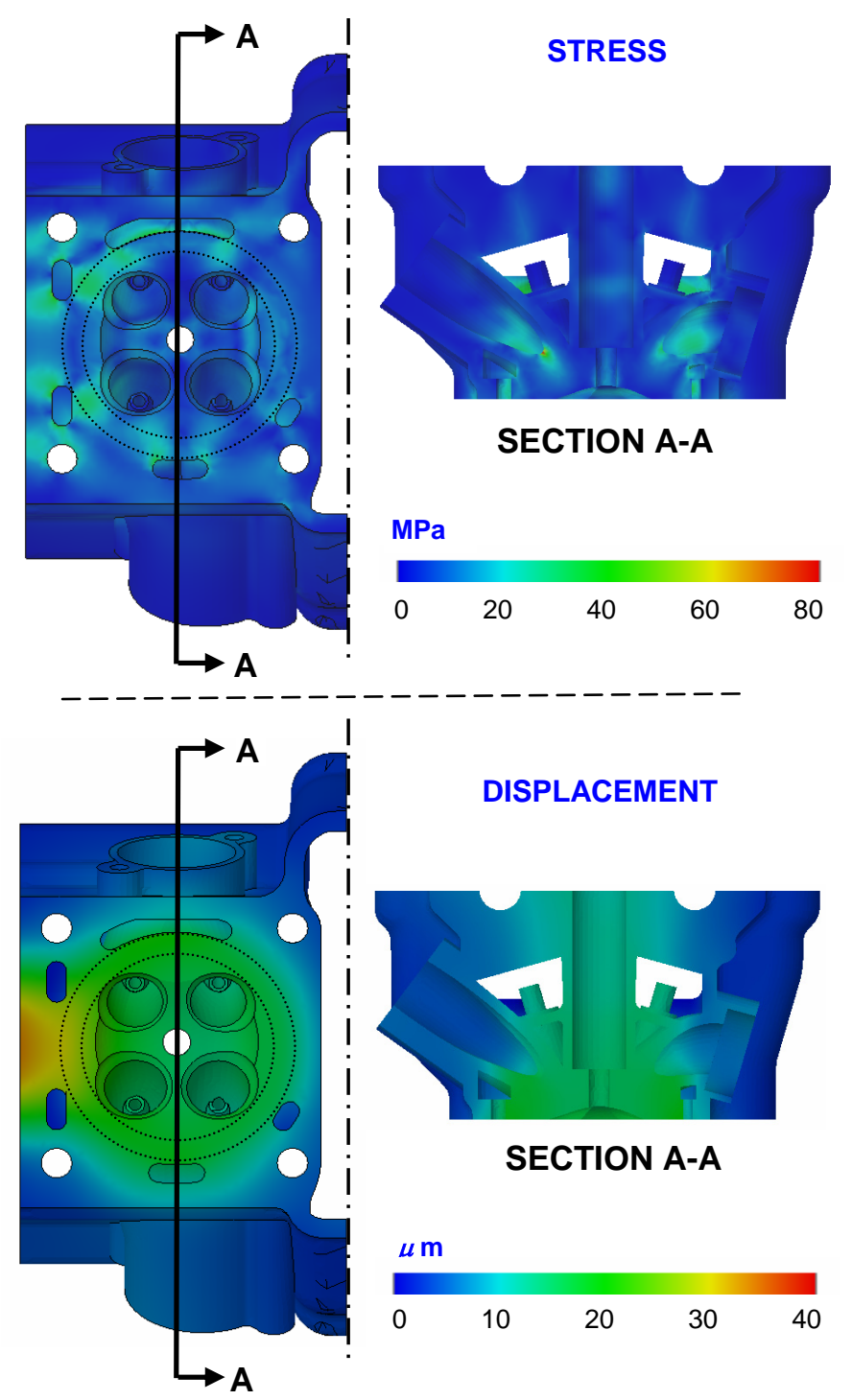

Figure 16: 1/2 FEM model analysis simulating the gasketless interface effects on the cylinder head. (top): Von Mises stress distribution. (bottom): Vertical displacement.

The deflection analysis of Figure 16 highlights the $20 \mu \mathrm{m}$ variation in the interface region. This value is similar in magnitude to the experimental test value and is a result of the cylinder head design, which allows more elastic deformation in the outer regions. The deflection corresponds to the region where interface failure occurred, due to the low cylinder head deck stiffness. However, successful sealing is apparent over the majority of the interface.

The cylinder head stress analysis shows that the loading due to the interface, produces only elastic deformation. The simulated peak stresses of $40 \mathrm{MPa}$ are well below the elastic limit for the material. Physical measurement of the cylinder head after disassembly also confirmed that there were no changes in surface flatness after initial testing. Thus, the interface leakage was resolved by increasing the interference to $80-90 \mu \mathrm{m}$ in order to accommodate the cylinder head deflection. Further FEM analysis ensured the material yield strength was not exceeded.

\section{DURABILITY TESTING}

A two year development program commenced after initial engine commissioning. This involved the commissioning of a stationary engine test cell facility as depicted in Figure 17. The test cell enabled steady state dynamometer testing, ensuring component and engine reliability. This included the integrity of the gasketless interface over several hundred hours of testing at a wide range of operating conditions.
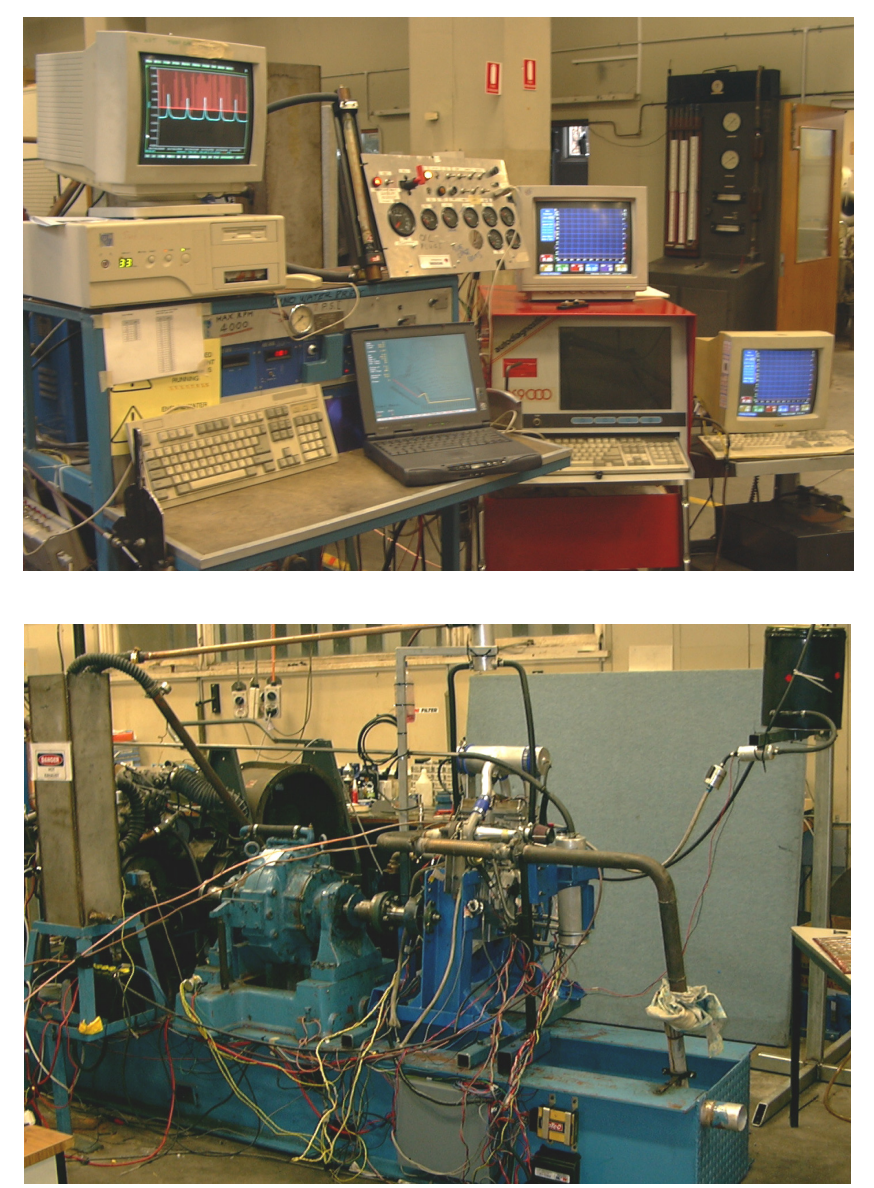

Figure 17: Stationary dynamometer test cell facility. (top): Control panel. (bottom): Dynamometer setup. 
Steady state dynamometer testing was combined with a transient testing program featuring the installation of the engine into two successive Formula SAE vehicles. Transient engine durability testing was thought to be risky due to the time restrictions and the unknown adequacy of the cooling and lubrication systems of the prototype vehicles. Also, all safeguards against engine and/or interface failure were significantly reduced. The MUR-03 vehicle with the first generation WATTARD engine is shown in Figure 18.

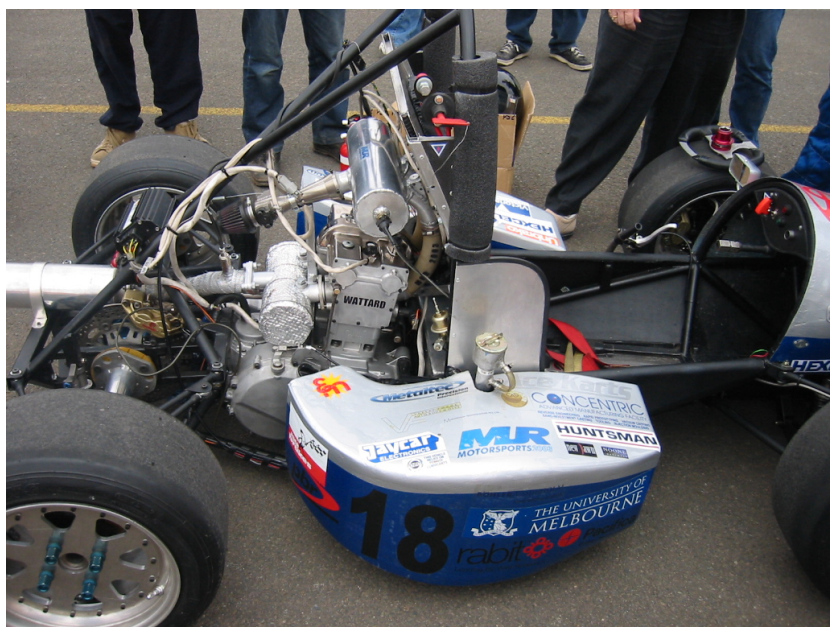

Figure 18: Transient durability testing with the UniMelb 'WATTARD' engine fitted to the MUR-03 Formula SAE vehicle.

\section{INTERFACE PERFORMANCE}

The gasketless interface was very successful, performing faultlessly in steady state and transient testing. No sign of any interface combustion gas or fluid leakage was evident after initial development. Piston ring seal and resulting blow-by rates were also reasonable, in comparison to published values for typical two compression ring piston designs $[9,25]$.

The sealing integrity of the interface is further demonstrated by the extreme conditions it withstood during engine testing. This included test conditions featuring sustained high knock intensities and engine overheating. Sealing integrity was maintained for peak cylinder pressures exceeding 100 bar, with combined knock amplitudes of 30 bar, as shown in Figure 19. The integrity of the interface is further highlighted by several piston meltdowns which occurred without interface failure. The resultant piston land failures were a result of knock due to inadequate water flow in the vehicle cooling system. Cylinder head water temperatures exceeding $130^{\circ} \mathrm{C}$ were recorded before piston land failure.

Durability testing also found that raw engine out $\mathrm{HC}$ emissions were significantly lower than those of similar engines operating at comparable conditions. This was due to the absence of any crevice volume near the interface, as can exist with conventional head gaskets. This amount of crevice volume is largely dependent on the alignment between the bore, gasket and combustion chamber and is eliminated in the gasketless design. Raw engine out $\mathrm{HC}$ emission concentrations as low as $25 \mathrm{ppm}$ were recorded, thus negating the need to use any emission control strategies to satisfy Euro $3 \mathrm{HC}$ emission standards [26].
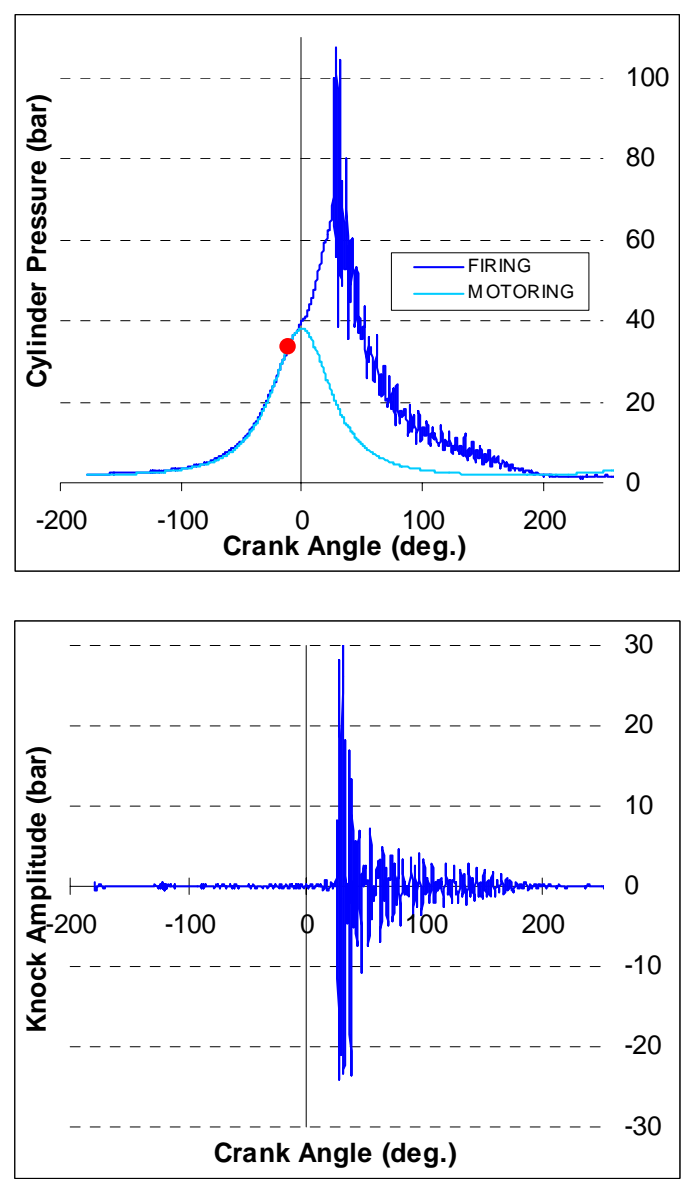

Figure 19: Successful operation of the gasketless interface when exposed to heavy knock conditions in the highly TC mode. $7000 \mathrm{rev} / \mathrm{min}, 11: 1 \mathrm{CR}, 220 \mathrm{kPa}$ MAP.

\section{INTERFACE EFFECTS}

Since the interference and resultant face pressure between the liner and cylinder head produces only elastic deformation, no adverse flatness effects on the mating surfaces of the assembly were recorded and no long term effects are expected. This is despite the frequent removal of the cylinder head during development for inspection and engine overhaul purposes. However, some adverse effects of the design do exist. As a result of both surfaces being in direct contact, the potential for local imprinting and/or fretting to occur on both surfaces exists. This however, could be argued to be no worse than in a conventional head gasket design. 
The absence of any gasket material also eliminates weakspots that may cause gasket failure due to abnormal combustion. This commonly occurs between cylinders and on the exhaust side due to higher thermal stresses locally reducing the surface pressure and exposing the gasket. This leaves no safety margin for novice calibrators with no form of knock detection. The gasketless interface has the potential to maintain combustion sealing until engine failure.

\section{CONCLUSIONS}

A $430 \mathrm{~cm}^{3}$ purpose designed and built highly TC two cylinder engine featuring a unique gasketless interface has been described.

The unforgiving operating conditions resulting from operating in the highly TC mode, led to the design and development of the new gasketless interface. Applying current day cylinder head gasket technology to this particular engine was considered to be risky and as such, a new solution was sought and developed.

During the design and development, extensive CAD, FEM and thermal analysis proved to be well suited to the task, with excellent agreement between simulations and actual results.

The new design featured many advantages and few drawbacks, in comparison to conventional gasket interface technology. A major advantage was the improvement of the structural integrity of the weaker open deck block design. This was achieved by increasing the local face pressure at the interface between the liner and cylinder head deck surface.

One of the major challenges during development was overcoming the bore distortion problems associated with the high face pressures generated between the cylinder head and liner assembly. This was overcome by altering the manufacturing process to include the final boring process after shrink fitting the liners into the cylinder block. Final dimensional tolerance was then achieved via torque plate honing.

The application of a gasketless interface reduces engine out $\mathrm{HC}$ emissions with simultaneous improvements in performance. This is due to the absence of any crevice volume near the interface, as can exist when conventional head gaskets are used.

The thermal analysis concluded that removing the conventional head gasket improves the heat flow between the cylinder head and barrel assembly. This is due to the absence of a gasket, which behaves as an insulator. The improved heat flow reduces the likelihood of hot spots forming around the periphery of the chamber, thus reducing the propensity of knock in the end-gas region.
The design has been proven to be extremely successful in withstanding the harshest of operating conditions, including severe combustion knock, overheating, incylinder pressures exceeding 100 bar and high combustion temperatures. The engine completed extensive static and transient testing with no interface problems after initial development. BMEP values in the order of 25 bar were recorded on pump gasoline at manifold absolute pressures (MAP) reaching $270 \mathrm{kPa}$.

\section{ACKNOWLEDGMENTS}

My personal thanks go to the Melbourne University MUR-03 and MUR-04 engine and electrics team for the many late nights and early mornings spent in the Thermodynamics lab. The team is also grateful, to all academic, postgraduate and technical staff involved for their persistence, patience and support during the most trying times of the engine development phase.

Thanks are also due to Associate Professor Peter Stryker for his extensive and thorough contribution to the thermal analysis presented in this paper, while on sabbatical leave from Bucknell University, Pennsylvania, USA.

To the generous sponsors that made the UniMelb "WATTARD" engine possible, we offer our sincere thanks for supporting the excellent learning activity at the University of Melbourne.

$\begin{array}{ll}>\text { ACL Bearing Company - } & \text { Tas, Australia } \\ >\text { APEP Pistons - } & \text { Vic, Australia } \\ >\text { Argo Engineering - } & \text { NSW, Australia } \\ >\text { Bishop Innovation - } & \text { NSW, Australia } \\ >\text { Bohler Uddeholm - } & \text { Vic, Australia } \\ >\text { CadCore Pty Ltd - } & \text { Vic, Australia } \\ >\text { Concentric Asia Pacific - } & \text { SA, Australia } \\ >\text { Cosway Motorcycles - } & \text { Vic, Australia } \\ >\text { Davies Craig - } & \text { Vic, Australia } \\ >\text { Electromold - } & \text { Vic, Australia } \\ >\text { Farley Laserlab - } & \text { Vic, Australia } \\ >\text { Garrett Honeywell - } & \text { NSW, Australia } \\ >\text { Kawasaki Australia - } & \text { NSW, Australia } \\ >\text { Magnesium Technologies - } & \text { Vic, Australia } \\ >\text { MAME Centre for Manufacturing - } & \text { Vic, Australia } \\ >\text { M\&W Ignitions - } & \text { NSW, Australia } \\ >\text { Penrite Lubricants - } & \text { Vic, Australia } \\ >\text { QMI Solutions - } & \text { Qld, Australia } \\ >\text { Ricardo - } & \text { Sussex, UK } \\ >\text { Robert Bosch - } & \text { Vic, Australia } \\ >\text { Siemans VDO - } & \text { Vic, Australia } \\ >\text { Southside Cylinder Heads - } & \text { Vic, Australia } \\ >\text { University of Melbourne - } & \text { Vic, Australia } \\ >\text { Wade Camshafts - } & \text { Vic, Australia } \\ >\text { Whitehorse Industries - } & \text { Vic, Australia }\end{array}$




\section{NOMENCLATURE}

$\begin{array}{ll}\text { BMEP } & \text { brake mean effective pressure } \\ \text { CA } & \text { crank angle } \\ \text { CAD } & \text { computer aided drawing } \\ \text { CAE } & \text { computer aided engineering } \\ \text { CNC } & \text { computer numerically controlled } \\ \text { DOHC } & \text { double over head camshafts } \\ \text { EMS } & \text { engine management system } \\ \text { EVC } & \text { exhaust valve closed } \\ \text { EVO } & \text { exhaust valve open } \\ \text { FEM } & \text { finite element method } \\ \text { HC } & \text { hydrocarbon } \\ \text { IVC } & \text { inlet valve closed } \\ \text { IVO } & \text { inlet vale open } \\ \text { KEC } & \text { kinetic energy conservation } \\ \text { MAP } & \text { manifold absolute pressure } \\ \text { MUR } & \text { Melbourne University Racing } \\ \text { NA } & \text { normally aspirated } \\ \text { PFI } & \text { port fuel injection } \\ \text { TC } & \text { turbocharged }\end{array}$

\section{REFERENCES}

1. CLOUGH, M.J., 'Precision Cooling of a Four Valve per Cylinder Engine', SAE paper 931123. (1993)

2. POEPPERI, M., HEDRICH, G., HEUSLER, H., KOEHLER, D., MARIN, B., ROTHENBERGER, P. and SCHARRER, O., 'Adaptation of a Dual Continuous Variable Cam Phasing to a 4-Valve, 4Cylinder Engine - Thermodynamic Benefits and Engine Hardware Requirements', SAE paper 200601-0408. (2006)

3. ROTHE, M., HEIDENREICH, T., SPICHER, U. and SCHUBERT, A., 'Knock Behaviour of SI Engines: Thermodynamic Analysis of Knock Onset Locations and Knock Intensities', SAE paper 2006-01-0225. (2006)

4. ATTARD, W, 'Design, Performance and Analysis of a Downsized Highly Turbocharged 0.45L Formula SAE Engine', Current Ph.D. Thesis, Mech. Eng. Dept., Univ. of Melbourne. (2006)

5. ATTARD, W. and WATSON, H.C., 'Development of a 430cc Constant Power Engine for FSAE Competition', SAE paper 2006-01-0745. (2006)

6. KARAGOUNIS, T. and STRAUS, 'Development of a 90 bhp Turbocharged Engine for use in Formula SAE-A', Undergraduate Thesis, Mech.Eng. Dept, Univ. of Melbourne. (2002)

7. ISHIGAKI, I., KITAGAWA, J. and TANAKA, A., 'New Evaluation Method of Metal Head Gasket', SAE paper 930122. (1993)

8. YAMAGUCHI, K., SATO, A., GOTO, E., FUJIKI, R., KAWAI, Y. and NAKATA, K., 'Development of a New Metal Cylinder Head Gasket', SAE paper 980844. (1998)
9. SCHNEIDER, E., BLOSSFELD, D., LECHMAN, D., HILL, R., REISING, F. and BREVICK, J., 'Effect of Cylinder Bore Out-of-Roundness on Piston Ring Rotation and Engine Oil Consumption, SAE paper 930796. (1993)

10. TAYLOR, C.F., 'The Internal Combustion Engine in Theory and Practice', Vol. 1 and 2, MIT Press, (1977)

11. HEYWOOD, J., 'Internal Combustion Engine Fundamentals', McGraw Hill,

12. ROSENKRANZ, H.G., WATSON, H.C., BRYCE, W. and LEWIS, A., 'Driveability fuel consumption and emissions of 1.3 litre turbocharged spark ignition engine developed as a replacement for a 2 litre normally aspirated engine.' Proc. I.Mech.E., C118/86:139-150 pp (1986)

13. WATSON, H.C., MILKINS, E.E., ROBERTS, K. and BRYCE, W., 'Turbocharging for fuel efficiency, SAE paper 830014. (1983)

14. ATTARD, W., WATSON, H.C. and KONIDARIS, S., 'Highly Turbocharging a Restricted Two Cylinder Small Engine - Turbocharger Development', SAE paper 07PFL-157. (2007)

15. ATTARD, W., WATSON, H.C. and KONIDARIS, S., 'Highly Turbocharging a Restricted, Odd Fire, Two Cylinder Small Engine - Design, Lubrication, Tuning and Control', SAE paper 06MSEC-38. (2006)

16. ATTARD, W., WATSON, H.C., KONIDARIS, S. and KHAN, M., 'Comparing the Performance and Limitations of a Downsized Formula SAE engine in Normally Aspirated, Supercharged and Turbocharged Modes', SAE paper 2006-32-0072. (2006)

17. GORR, E., KERR, C., STEVENS, K. and ARCHER, J., 'Techniques for Manufacturing and Coating Liners of Small Engines', SAE paper 2000-01-0904. (2001)

18. RODRIGUES, M. and PORTO, S., 'Torque Plate Honing on Block Cylinder Bores', SAE paper 931679. (1993)

19. WOSCHNI, G., 'A Universally Applicable Equation for the Instantaneous Heat Transfer Coefficient in the Internal Combustion Engine', SAE paper 670931. (1967)

20. MOREL, T. and KERIBAR, R., 'A Model for Predicting Spatially and Time Resolved Convective Heat Transfer in Bowl-in-Piston Combustion Chambers', SAE paper 850204. (1985)

21. CATON, J. and HEYWOOD, J., 'An Experimental and Analytical Study of Heat Transfer in an Engine Exhaust Port', Int. J. Heat Mass Transfer, Vol 24, No. 4, pp 581-595 (1981)

22. BANIASAD, S., KHALIL, E. and SHEN, F., 'Exhaust Valve Thermal Management and Robust Design Using Combustion and 3D Conjugate Heat Transfer 
Simulation with 6-Sigma Methodology', SAE paper 2006-01-0889. (2006)

23. CHANG, J., GURALP, O., FILIPI, Z., ASSANIS, D., KUO, T., NAJT, P. and RASK, R., 'New Heat Transfer Correlation for an $\mathrm{HCCl}$ Engine Derived from Measurements of Instantaneous Surface Heat Flux', SAE paper 2004-01-2996. (2004)

24. ALKIDAS, A., 'Effects of Operational Parameters on Structural Temperatures and Coolant Heat Rejection of a S.I Engine', SAE paper 931124. (1993)

25. TOMANIK, E., SOBRINHO, R.M.S. and ZECCHINELLI, R., 'Influence of Top Ring Gap Types at Blow-By of Internal Combustion Engines', SAE paper 931669. (1993)

26. HAMORI, F., 'Exploring the Limits of Hydrogen Assisted Jet Ignition', Ph.D. Thesis, Mech.Eng. Dept, Univ. of Melbourne, (2006)

\section{CONTACT}

Prof. Harry Watson

Head Thermofluids Group

Department of Mechanical Engineering

University of Melbourne

Victoria, Australia, 3010

Email: harrycw@unimelb.edu.au

William Attard

Thermofluids Group

Department of Mechanical Engineering

University of Melbourne,

Victoria, Australia, 3010

Email: william_attard@hotmail.com 


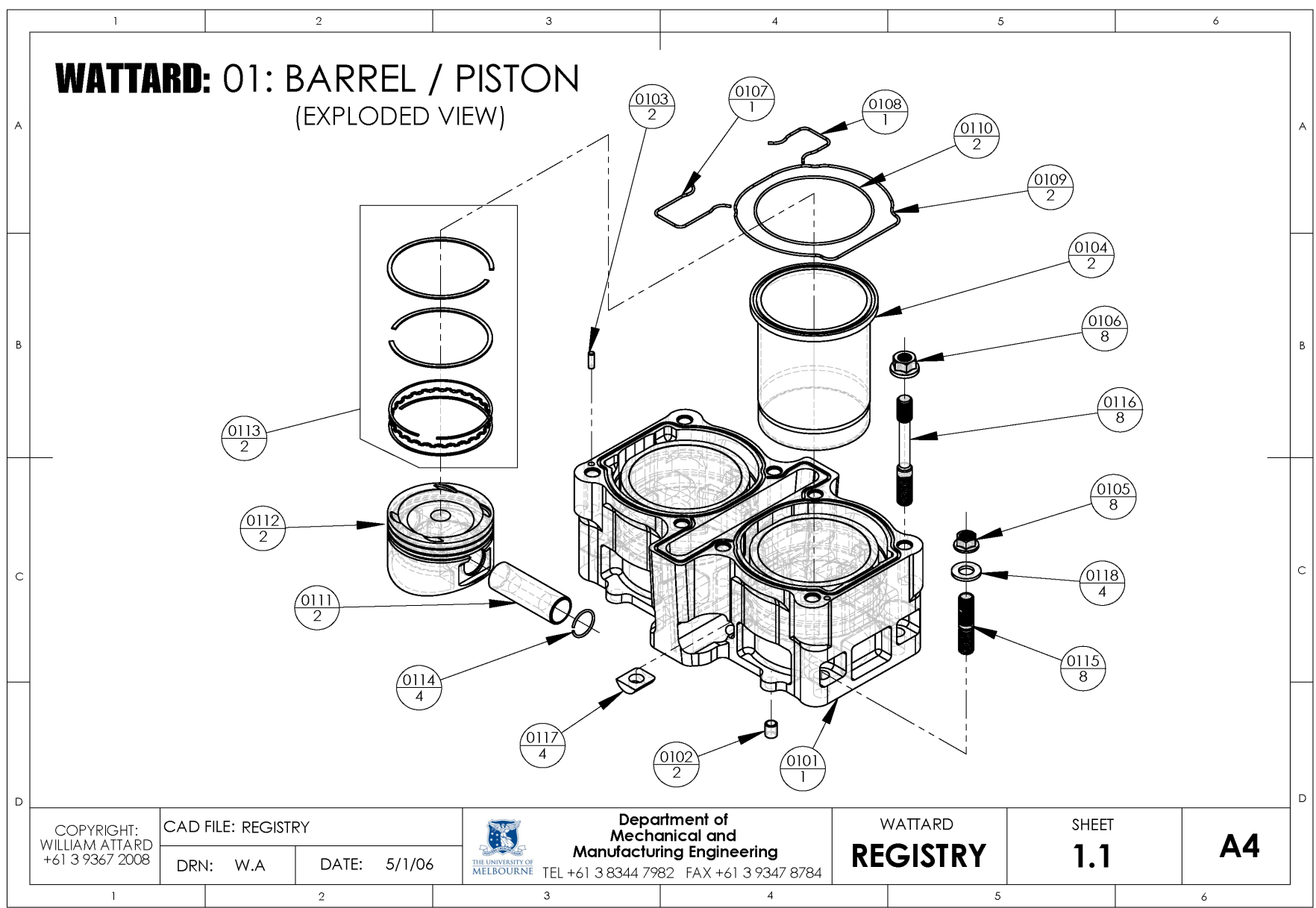

WATTARD: 01: BARREL / PISTON

(ASSEMBLY \& PARTS)

ASSEMBLY INDEX

\begin{tabular}{|c|c|c|c|}
\hline ASSY \# & DESCRIPTION & CAD FILE & DRAWING \# \\
\hline 0001 & Barrel / Piston & 0001 Barrel / Piston Assy & 001 \\
\hline
\end{tabular}

PART INDEX

\begin{tabular}{|c|c|l|l|c|}
\hline PART \# & QTY & \multicolumn{1}{|c|}{ DESCRIPTION } & \multicolumn{1}{|c|}{ CAD FILE } & DRAWING \# \\
\hline 0101 & 1 & Barrel-engine & 0101 Barrel-engine & 0101 \\
\hline 0102 & 2 & Dowell-hollow (barrel to case) & 0102 Dowell-hollow (barrel to case) & 0102 \\
\hline 0103 & 2 & Dowell-solid (barrel to head) & 0103 Dowell-solid (barrel to head) & 0103 \\
\hline 0104 & 2 & Liner-cylinder & 0104 A Liner-cylinder (std) & $0104 \mathrm{~A}$ \\
& & & $0104 \mathrm{~B}$ Liner-cylinder (+1.0) & $0104 \mathrm{~B}$ \\
\hline 0105 & 8 & Nut-flanged (barrel to case) & 0105 Nut-flanged (barrel to case) & 0105 \\
\hline 0106 & 8 & Nut-flanged (barrel to head) & 0106 Nut-flanged (barrel to head) & 0106 \\
\hline 0107 & 1 & O-ring (barrel to head oil ex) & 0107 O-ring (barrel to head oil ex) & 0107 \\
\hline 0108 & 1 & O-ring (barrel to head oil in) & 0108 O-ring (barrel to head oil in) & 0108 \\
\hline 0109 & 2 & O-ring (barrel to head water) & 0109 O-ring (barrel to head water) & 0109 \\
\hline 0110 & 2 & O-ring (liner to head) & 0110 O-ring (liner to head) & 0110 \\
\hline 0111 & 2 & Pin-piston & 0111 Pin-piston & 0111 \\
\hline & & & $0112 \mathrm{~A}$ Piston (std 12.9:1 CR Ring A) & $0112 \mathrm{~A}$ \\
& & & $0112 \mathrm{~B}$ Piston (std 12.9:1 CR Ring B) & $0112 \mathrm{~B}$ \\
0112 & 2 & Piston & 0112 C Piston (std 12.9:1 CR Ring C) & $0112 \mathrm{C}$ \\
& & & $0112 \mathrm{D}$ Piston (std 11:1 CR Ring D) & $0112 \mathrm{D}$ \\
& & & $0112 \mathrm{E}$ Piston (std 9.6:1 CR Ring D) & $0112 \mathrm{E}$ \\
\hline & & & $0112 \mathrm{~F}$ Piston (+1.0 10.0:1 CR Ring E) & $0112 \mathrm{~F}$ \\
\hline 0113 & 2 & Rings-piston & $0113 \mathrm{~A}$ Rings-piston A (1.0 2.8) & $0113 \mathrm{~A}$ \\
& & & $0113 \mathrm{~B}$ Rings-piston B (1.0 1.2 2.8) & $0113 \mathrm{~B}$ \\
\hline 0114 & 4 & Ring-snap (piston pin) & 0113 C Rings-piston C (1.0 2.8) & $0113 \mathrm{C}$ \\
\hline 0115 & 8 & Stud (barrel to case) & $0113 \mathrm{D}$ Rings-piston D (1.2 2.8) & $0113 \mathrm{D}$ \\
\hline 0116 & 8 & Stud (barrel to head) & $0113 E$ Rings-piston E (1.0 1.2 2.8) & $0113 \mathrm{E}$ \\
\hline 0117 & 4 & Washer-curved (inner barrel to case) & 0114 Ring-snap (piston pin) & 0114 \\
\hline 0118 & 4 & Washer-flat (outer barrel to case) & 0115 Stud (barrel to case) & 0115 \\
\hline
\end{tabular}




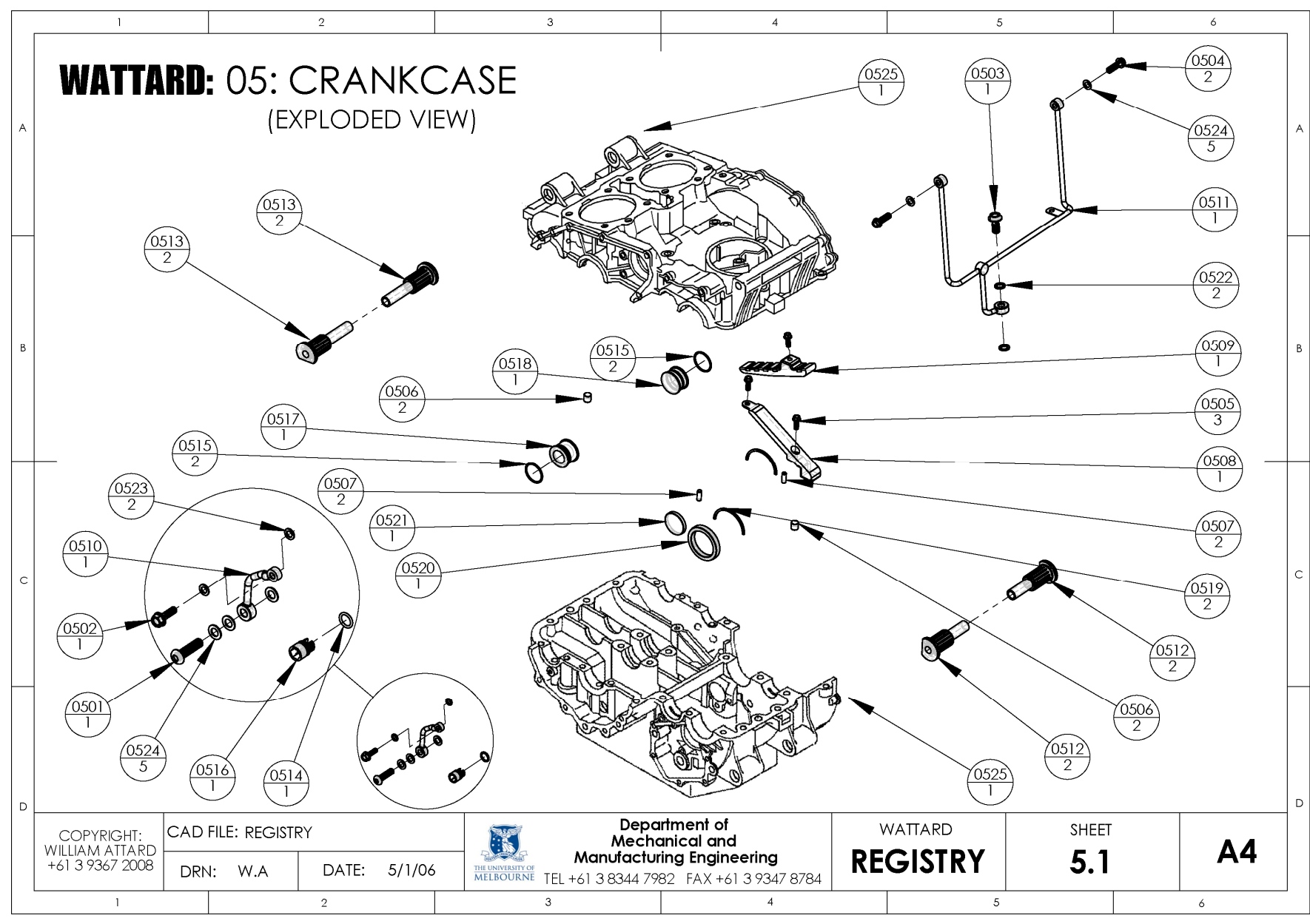

WATTARD: 05: CRANKCASE

(ASSEMBLY \& PARTS)

ASSEMBLY INDEX

\begin{tabular}{|c|c|c|c|}
\hline ASSY\# & DESCRIPTION & CAD FILE & DRAWING \# \\
\hline 0005 & Crankcase & 0005 Crankcase Assy & 0005 \\
\hline
\end{tabular}

PART INDEX

\begin{tabular}{|c|c|c|c|c|}
\hline PART \# & QTY & DESCRIPTION & CAD FILE & DRAWING \# \\
\hline 0501 & 1 & Bolt-banjo (clutch oil feed line to case) & 0501 Bolt-banjo M8 (clutch oil feed line to case) & 0501 \\
\hline 0502 & 1 & Bolt-banjo (clutch oil feed line to clutch) & 0502 Bolt-banjo M6 (clutch oil feed line to clutch) & 0502 \\
\hline 0503 & 1 & Bolt-banjo (head oil feed line to case) & 0503 Bolt-banjo M10 (head oil feed line to case) & 0503 \\
\hline 0504 & 2 & Bolt-banjo (head oil feed line to head) & 0504 Bolt-banjo M8 fine (head oil feed line to head) & 0504 \\
\hline 0505 & 3 & Bolt-flanged (chain guide) & 0505 Bolt-flanged M6×16 (chain guide) & 0505 \\
\hline 0506 & 2 & Dowell-solid (crankcase alignment) & 0506 Dowell-solid 10x12 (crankcase alignment) & 0506 \\
\hline 0507 & 2 & Dowell-solid (transmission endfloat alignment) & 0507 Dowell-solid 6x16 (transmission endfloat alignment) & 0507 \\
\hline 0508 & 1 & Guide-chain (primary slack side) & 0508 Guide-chain (primary slack side) & 0508 \\
\hline 0509 & 1 & Guide-chain (primary tight side) & 0509 Guide-chain (primary tight side) & 0509 \\
\hline 0510 & 1 & Line-oil (clutch feed) & 0510 Line-oil (clutch feed) & 0510 \\
\hline 0511 & 1 & Line-oil (cylinder head feed) & 0511 Line-oil (cylinder head feed) & 0511 \\
\hline 0512 & 2 & Mount-engine (exhaust side) & 0512 Mount-engine (exhaust side) & 0512 \\
\hline 0513 & 2 & Mount-engine (intake side) & 0513 Mount-engine (intake side) & 0513 \\
\hline 0514 & 1 & O-ring (main oil gallery plug) & 0514 O-ring $11 \times 2$ (main oil gallery plug) & 0514 \\
\hline 0515 & 2 & O-ring (nylon plug) & 0515 O-ring $27 \times 2$ (nylon plug) & 0515 \\
\hline 0516 & 1 & Plug (main oil gallery) & 0516 Plug (main oil gallery) & 0516 \\
\hline 0517 & 1 & Plug-nylon (balance shaft cyl 1) & 0517 Plug-nylon (balance shaft cyl 1) & 0517 \\
\hline 0518 & 1 & Plug-nylon (balance shaft cyl 2) & 0518 Plug-nylon (balance shaft cyl 2) & 0518 \\
\hline 0519 & 2 & Ring (transmission alignment) & 0519 Ring (transmission alignment) & 0519 \\
\hline 0520 & 1 & Seal-lip (transmission output shaft) & 0520 Seal-lip $52 \times 40 \times 8$ (transmission output shaft) & 0520 \\
\hline 0521 & 1 & Seal-rubber (transmission input shaft) & 0521 Seal-rubber (transmission input shaft) & 0521 \\
\hline 0522 & 2 & Washer-sealing (10mm banjo bolt) & 0522 Washer-sealing (10mm banjo bolt) & 0522 \\
\hline 0523 & 2 & Washer-sealing (6mm banjo bolt) & 0523 Washer-sealing (6mm banjo bolt) & 0523 \\
\hline 0524 & 5 & Washer-sealing ( $8 \mathrm{~mm}$ banjo bolt) & 0524 Washer-sealing (8mm banjo bolt) & 0524 \\
\hline 0525 & 1 & Crankcase & 0525 Crankcase & 0525 \\
\hline
\end{tabular}

○

\begin{tabular}{l|l} 
COPYRIGHT: & CAD FILE: REGISTRY
\end{tabular} 


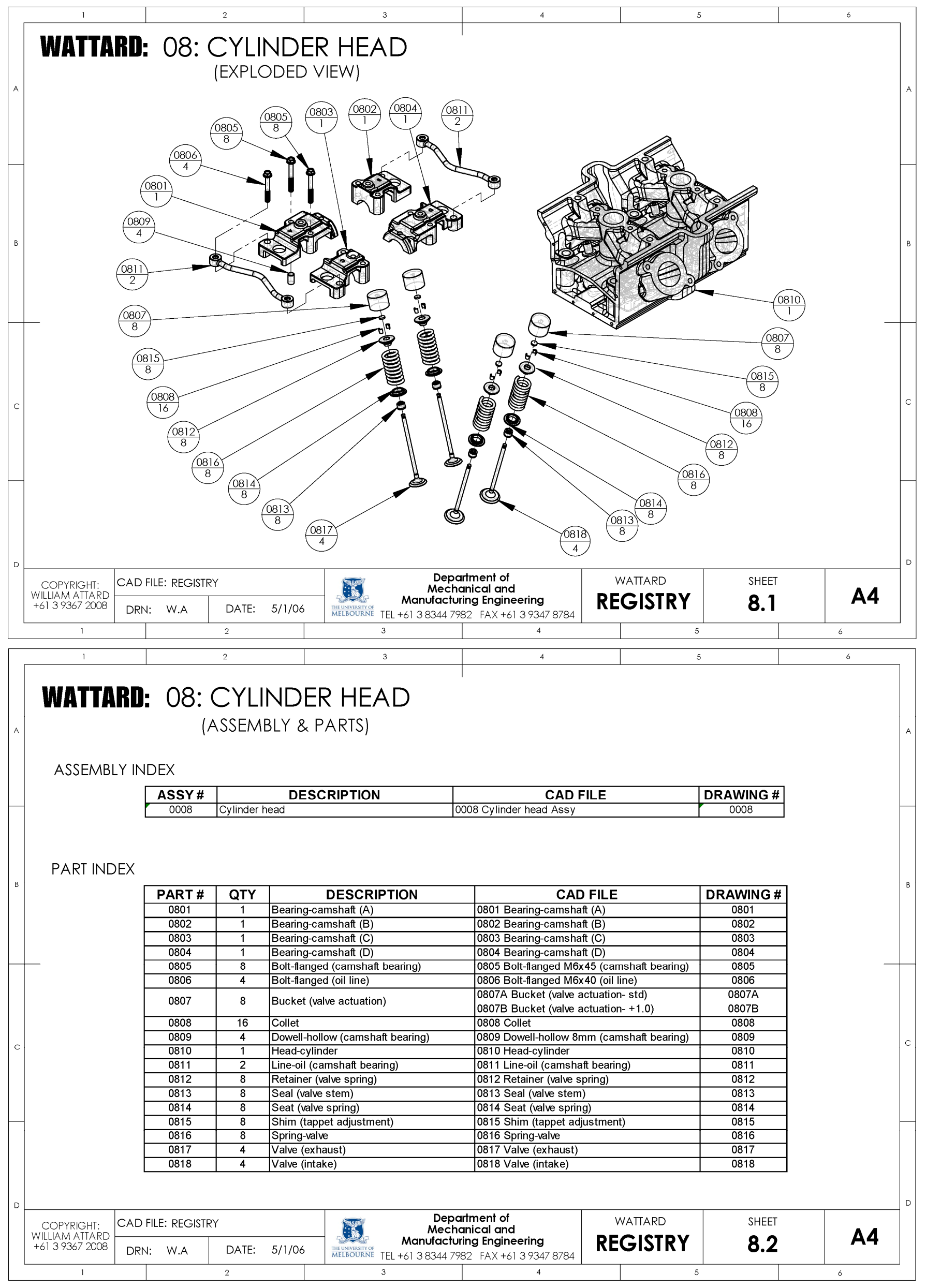




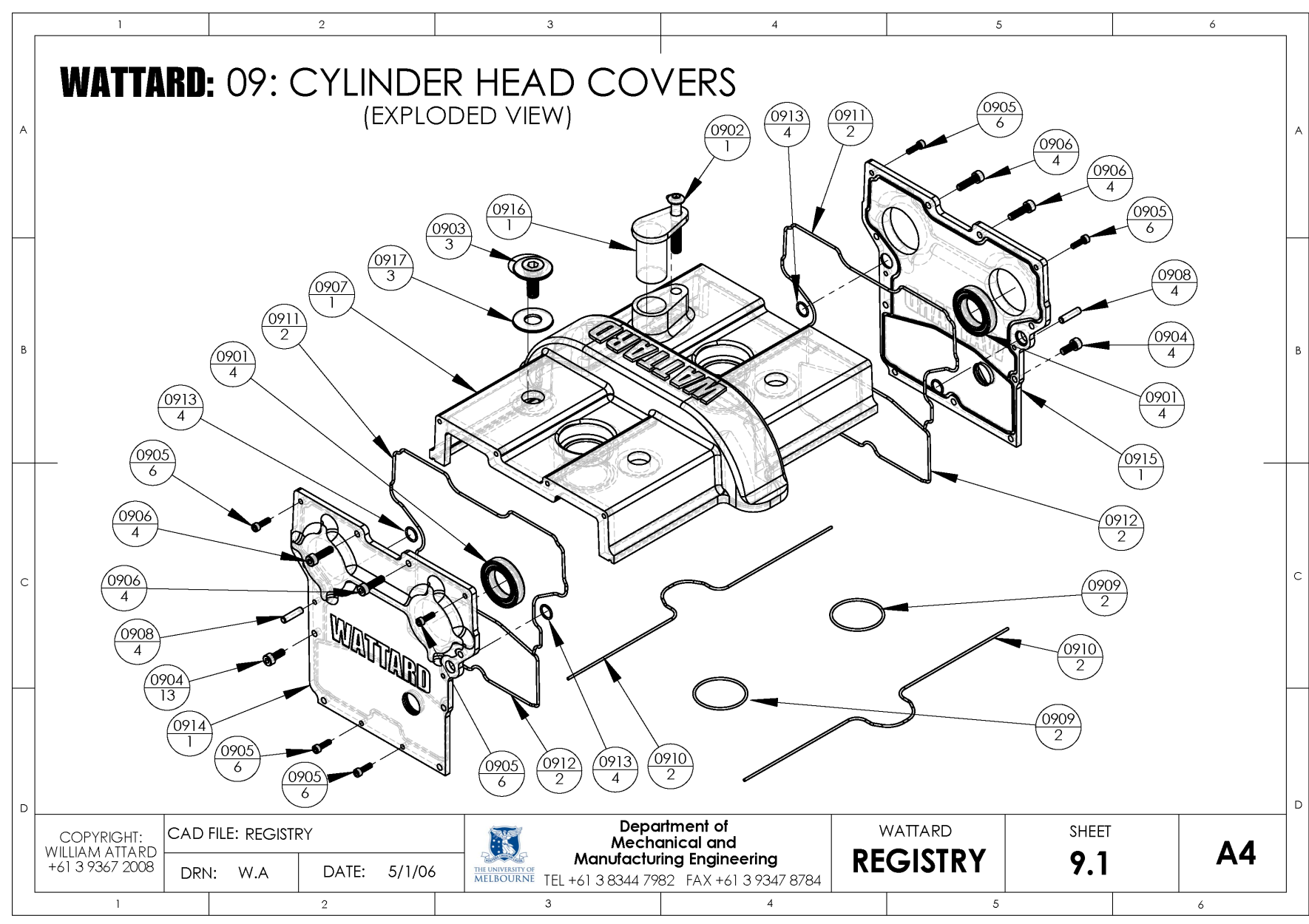

WATTARD: 09: CYLINDER HEAD COVERS

(ASSEMBLY \& PARTS)

ASSEMBLY INDEX

\begin{tabular}{|c|l|l|c|}
\hline ASSY \# & \multicolumn{1}{|c|}{ DESCRIPTION } & CAD FILE & DRAWING \# \\
\hline 0009 & Cylinder head covers & 0009 cylinder head cover Assy & 0009 \\
\hline
\end{tabular}

PART INDEX

\begin{tabular}{|c|c|l|l|c|}
\hline PART \# & QTY & \multicolumn{1}{|c|}{ DESCRIPTION } & \multicolumn{1}{|c|}{ CAD FILE } & DRAWING \# \\
\hline 0901 & 4 & Bearing-ball (side plate) & 0901 Bearing-ball 32x20x7 (side plate) & 0901 \\
\hline 0902 & 1 & Bolt-BHSS (cam sensor) & 0902 Bolt-BHSS M6x40 (cam sensor) & 0902 \\
\hline 0903 & 3 & Bolt-flanged (rocker cover) & 0903 Bolt-flanged M7 (rocker cover) & 0903 \\
\hline 0904 & 13 & Bolt-SHCS (side plate to head) & 0904 Bolt-SHCS M4x10 (side plate to head) & 0904 \\
\hline 0905 & 6 & Bolt-SHCS (side plate to rocker cover) & 0905 Bolt-SHCS M3x10 (side plate to rocker cover) & 0905 \\
\hline 0906 & 4 & Bolt-SHCS (side plate to rocker cover) & 0906 Bolt-SHCS M4x 15 (side plate to rocker cover) & 0906 \\
\hline 0907 & 1 & lover-rocker & 0907 Cover-rocker & 0907 \\
\hline 0908 & 4 & Dowell-soild (side plate to head) & 0908 Dowell-soild 4x16 (side plate to head) & 0908 \\
\hline 0909 & 2 & O-ring (rocker cover spark plug hole) & 0909 O-ring (rocker cover spark plug hole) & 0909 \\
\hline 0910 & 2 & O-ring (rocker cover to head) & 0910 O-ring (rocker cover to head) & 0910 \\
\hline 0911 & 2 & O-ring (side plate to head for oil) & 0911 O-ring (side plate to head for oil) & 0911 \\
\hline 0912 & 2 & O-ring (side plate to head for water) & 0912 O-ring (side plate to head for water) & 0912 \\
\hline 0913 & 4 & O-ring (side plate to head oil gallery) & 0913 O-ring (side plate to head oil gallery) & 0913 \\
\hline 0914 & 1 & Plate-side (cylinder 1) & 0914 Plate-side (cylinder 1) & 0914 \\
\hline 0915 & 1 & Plate-side (cylinder 2) & 0915 Plate-side (cylinder 2) & 0915 \\
\hline 0916 & 1 & Sensor-hall (camshaft syncronisation) & 0916 Sensor-hall (camshaft syncronisation) & 0916 \\
\hline 0917 & 3 & Washer-rubber (rocker cover bolt) & 0917 Washer-rubber (rocker cover bolt) & 0917 \\
\hline
\end{tabular}




\section{University Library}

\section{- M M I N E R VA \\ A gateway to Melbourne's research publications}

Minerva Access is the Institutional Repository of The University of Melbourne

Author/s:

Attard, William;Watson, Harry;Stryker, Peter

Title:

Design and development of a gasketless cylinder head / block interface for an open deck, multi cylinder, highly turbocharged small engine

Date:

2006

Citation:

Attard, W., Watson, H., \& Stryker, P. (2006). Design and development of a gasketless cylinder head / block interface for an open deck, multi cylinder, highly turbocharged small engine. In, Proceedings, SAE International Small Engine Technology Conference, San Antonio, Texas, USA.

Publication Status:

Published

Persistent Link:

http://hdl.handle.net/11343/34451 